000244

A. $\pi$. Bruee - 1992

Periclimenes lacertac. Pl priadactylura eta 



\title{
Two New Species of Periclimenes (Crustacea: Decapoda: Palaemonidae) from Lizard Island, Queensland, with Notes on Some Related Taxa
}

\author{
A.J. BRuCE \\ Division of Natural Sciences, Northern Territory Museum, \\ PO Box 4646, Darwin, NT 0801, Australia
}

\begin{abstract}
Two new species of Periclimenes caught in traps at Lizard Island, Queensland, $P$. lacertae and $P$. priodactylus, are described. Periclimenes denticulatus Nobili, P. agag Kemp and Periclimenes laccadivensis (Alcock \& Anderson) are reported from Australia for the first time. Further information is presented on other Australian specimens of Periclimenes, $P$. platycheles Holthuis, P. attenuatus Bruce, $P$. amboinensis (De Man), and on Parapontonia nudirostris Bruce, with remarks on some non-Australian specimens of Periclimenes, $P$. lanipes Kemp, $P$. pholeter Holthuis and " $P$. consobrinus" Balss (non De Man). The extraordinary occurrence of $P$. pholeter in traps at $1825 \mathrm{~m}$ in the Red Sea, previously known only from anchialine habitats, represents the greatest depth from which a palaemonid shrimp has so far been recorded. Its first occurrence in the western Pacific Ocean is also recorded.
\end{abstract}

Bruce, A.J., 1992. Two new species of Periclimenes (Crustacea: Decapoda: Palaemonidae) from Lizard Island, Queensland, with notes on some related taxa. Records of the Australian Museum 44(1): 45-84.

Very few pontoniine shrimps have been reported from traps and the few records have been of deep-water species. It is therefore of interest that small traps set in shallow water at Lizard Island, Queensland, by Dr J.K. Lowry and S.J. Keable, have provided specimens of two undescribed species of Periclimenes, $P$. lacertae n.sp., and $P$. priodactylus n.sp., and one very poorly known species, $P$. denticulatus Nobili. Other Periclimenes species of interest were also caught in the traps, and are discussed in this report. Further pontoniine material also included in this report is derived from a study of the commensal associates of crinoids on the northern Great Barrier Reef carried out by Ms K. Fabricius. The first Australian specimen of Periclimenes laccadivensis (Alcock \& Anderson) from $720 \mathrm{~m}$, off Cape Freycinet, Tasmania, is also reported. Additional information is also provided upon the Pola Expedition material referred to $P$. consobrinus by Heinrich Balss (1915) and on specimens of $P$. brocki from Singapore Straits by Johnson (1961, 1979). Recent collections of $P$. pholeter from deep-water traps in the central Red Sea, from R.V. Meteor material, are also recorded and further specimens 
are also reported from shallow anchialine water from Fiji, the first occurrence of this species in the Western Pacific Ocean.

Carapace length $(\mathrm{CL})$ refers to the postorbital carapace length. Abbreviations for institutions are as follows: AM - Australian Museum, Sydney; NTM - Northern Territory Museum, Darwin; NHMV - Naturhistorisches Museum, Wien; NMV - Museum of Victoria, Melbourne; RMNH - Rijksmuseum van Natuurlijke Historie, Leiden.

The species examined in this paper are: Periclimenes lacertae n.sp., Periclimenes priodactylus n.sp., Periclimenes denticulatus Nobili, 1906, Periclimenes platycheles Holthuis, 1952, Periclimenes agag Kemp, 1922, Periclimenes amboinensis (De Man, 1888), Periclimenes attenuatus Bruce, 1971, Periclimenes laccadivensis (Alcock \& Anderson, 1894), "Periclimenes consobrinus" Balss, 1915, Periclimenes pholeter Holthuis, 1973, Periclimenes lanipes Kemp, 1922, and Parapontonia nudirostris Bruce, 1968.

\section{Periclimenes lacertae n.sp.}

Figs 1-6

Material examined. 1 male, stn Qld-197, off
Chinaman's Ridge, Mrs Watson's Bay, Lizard Island, 22-33 m, trap, 20-21 Jan. 1989, coll. J.K. Lowry, S.J. Keable.

Description. Medium-sized shrimp, slender subcylindrical body form.

Carapace glabrous, smooth, with rostrum long, slender, straight, horizontal, about 1.85 times carapace length, lateral carinae obsolete, dorsal margin with 10 acute teeth, first tooth slightly anterior to posterior orbital margin, first 10 evenly spaced, distal 2 smaller, closer, subterminal interspaces with 2-3 short setae proximally, lower margin with 6 acute teeth, first situated below fourth dorsal tooth, of slightly decreasing size and spacing distally, interspaces with double row of numerous setae, proximal to first ventral tooth with single median row of setae; epigastric tooth present, slightly posterior to level of hepatic tooth, supraorbital spines absent, orbit obsolete, inferior orbital angle distinct, feeble, antennal spine slender, acute, marginal, below level of inferior orbital angle, hepatic spine slender, acute, below level of antennal spine, at about 0.15 of carapace length, anterolateral angle of branchiostegite bluntly obtuse.

Abdomen glabrous, smooth, third segment not posterodorsally produced, fifth segment about 0.5 of length of sixth, sixth moderately compressed, about 1.5

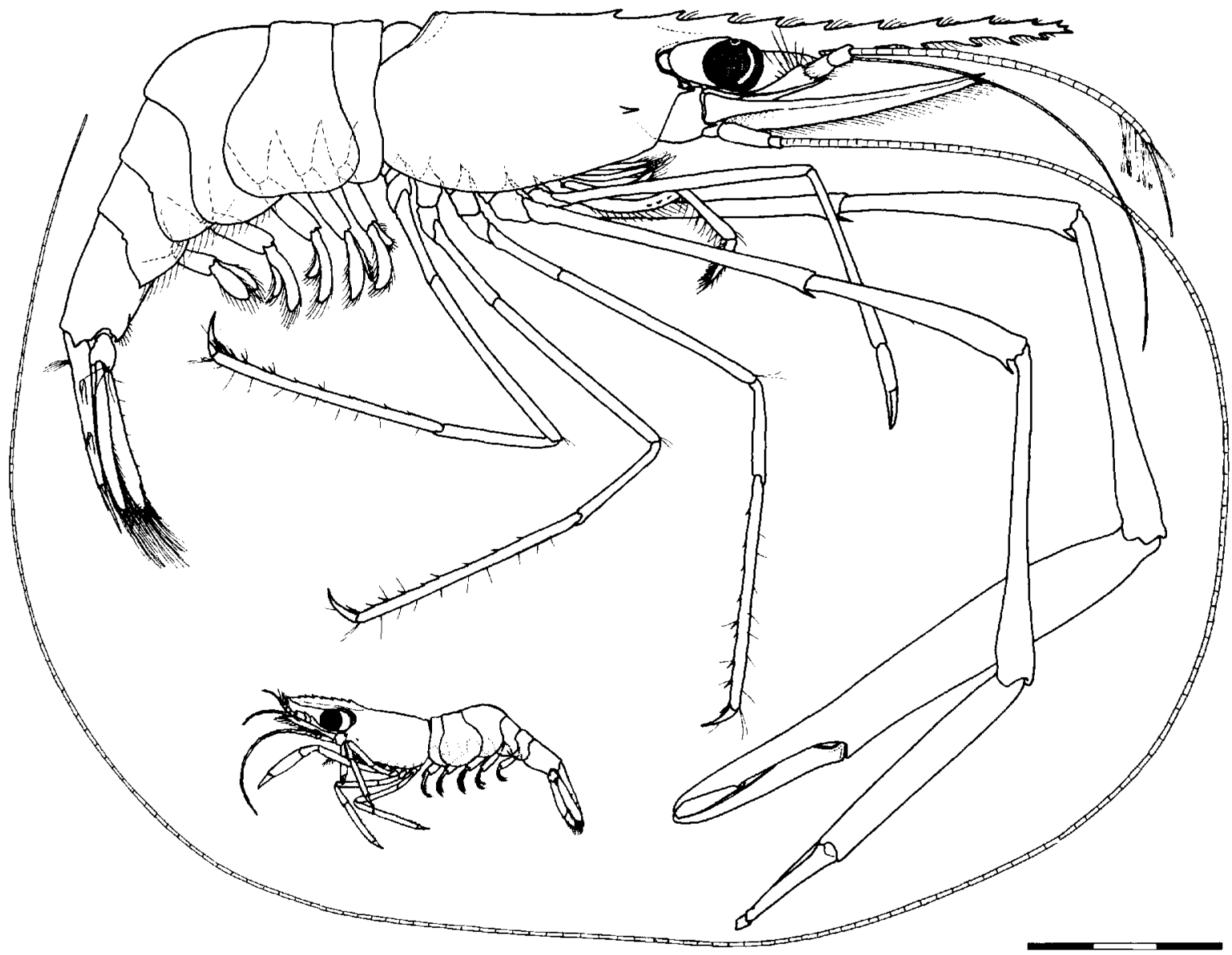

Fig.1. Periclimenes lacertae n.sp., holotype male, Lizard Island, Queensland, scale bar in millimetres. Inset, $P$. priodactylus n.sp., at same scale. 
times longer than deep, subuniform, posterolateral angle produced, acute, posteroventral angle produced, with small acute posterior tooth, ventral margin setose, pleura of first 3 segments broadly rounded, fourth slightly posteriorly produced, rounded, fifth posteriorly produced, posteroventral angle acutely pointed, third to fifth pleura with ventral margins setose; telson about 1.4 of sixth segment length, about 3.0 times longer than

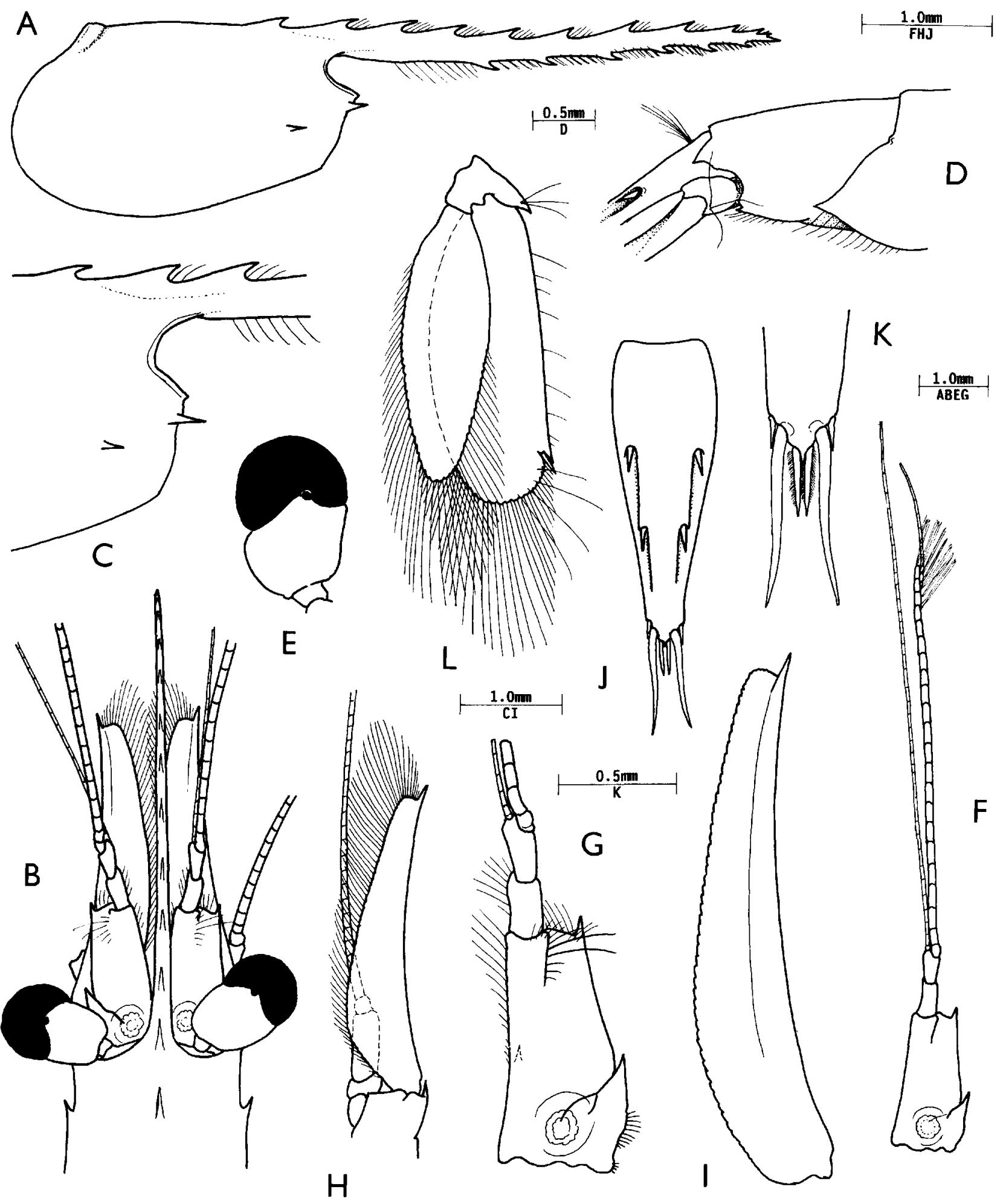

Fig.2. Periclimenes lacertae n.sp., holotype male. A, carapace and rostrum; B, anterior carapace, rostrum, eyes and antennal peduncles, dorsal; $\mathrm{C}$, orbital region, lateral; $\mathrm{D}$, posterior abdomen, lateral; $\mathrm{E}$, eye; F, antennule; G, same, peduncle; H, antenna; I, scaphocerite; J, telson; K, same, posterior spines; L, uropod. 
wide, maximum width at about 0.3 of length, lateral margins sinuous, posteriorly convergent, with 2 pairs of stout dorsal spines, at 0.33 and 0.6 of telson length, set proximally in deep longitudinal grooves, spines about 0.85 of telson length, posterior margin about 0.35 of telson width, acute, with acute median point, with 3 pairs of spines, lateral spines smaller than dorsal spines, about 0.2 of intermediate spine length, intermediate spines long, sinuous, 0.3 of telson length, 7.0 times longer than wide, submedian spines short, stout, straight, very acute distally, 0.43 of intermediate spine length, 7.0 times longer than proximal width, finely setulose medially and laterally.
Eye with large, globular, cornea well pigmented, with small dorsal accessory pigment spot; stalk moderately compressed, about as wide as long, length about 0.8 of corneal diameter.

Antennule with peduncle reaching to halfway between fourth and fifth dorsal rostral teeth; proximal segment about 2.2 times longer than wide, medial margin straight, setose, with acute ventral tooth at 0.45 of length, lateral margin feebly concave, convergent distally, distolateral angle not produced, setose ventrally, with acute distolateral tooth; stylocerite short, acute, reaching to 0.4 of segment length, lateral margin proximally with short plumose setae; statocyst well developed, with

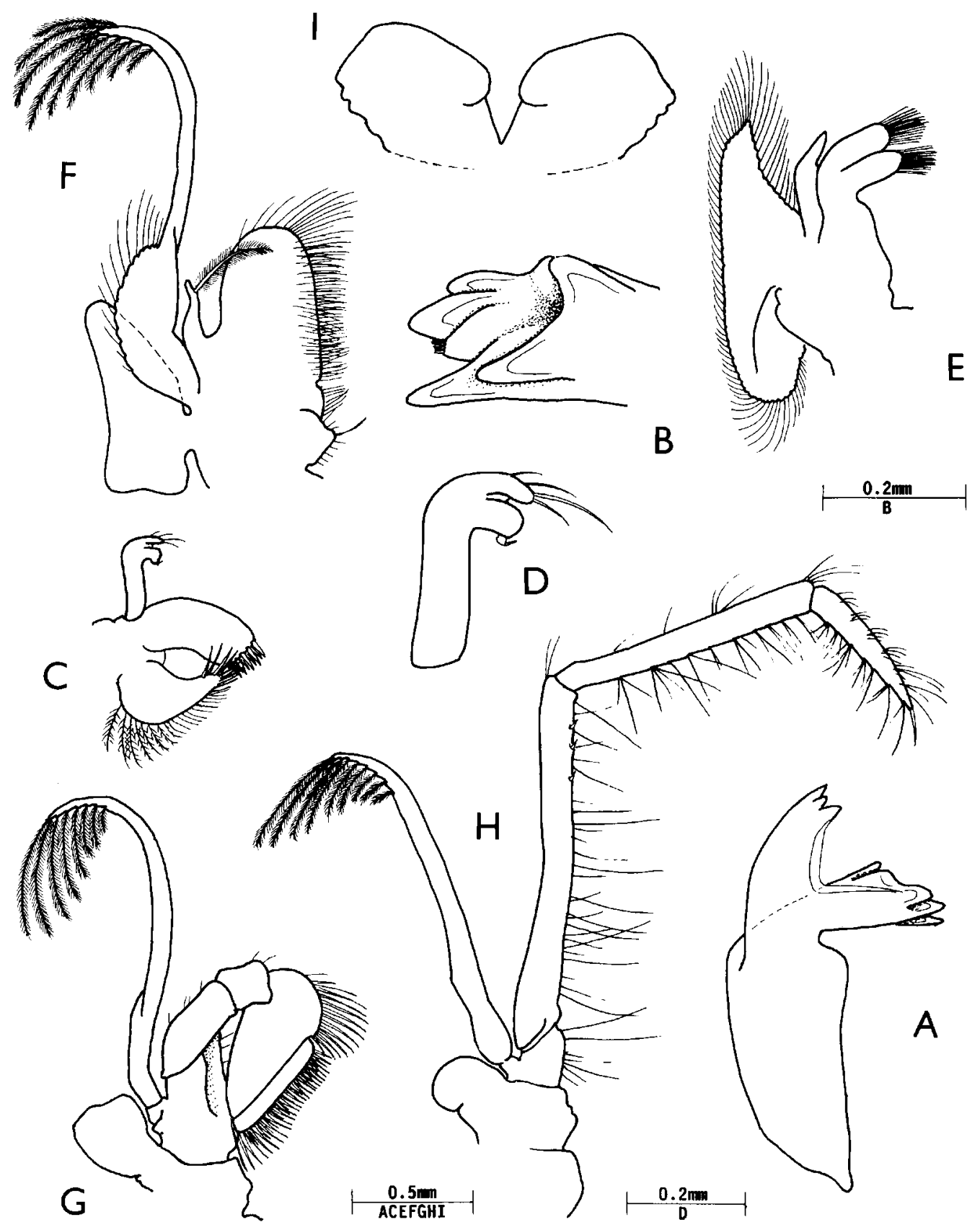

Fig.3. Periclimenes lacertae n.sp., holotype male. A, mandible; B, same, molar process; C, maxillula; D, same, palp; E, maxilla; F, first maxilliped; G, second maxilliped; H, third maxilliped; I, paragnaths. 
discoid statolith; distal dorsal surface with longitudinal row of setae, with 2 very long, densely setulose; intermediate segment 1.8 times longer than wide, 0.25 of proximal segment length, with small medial setose lamella; distal segment about 1.2 times intermediate segment length, 2.0 times longer than distal width,

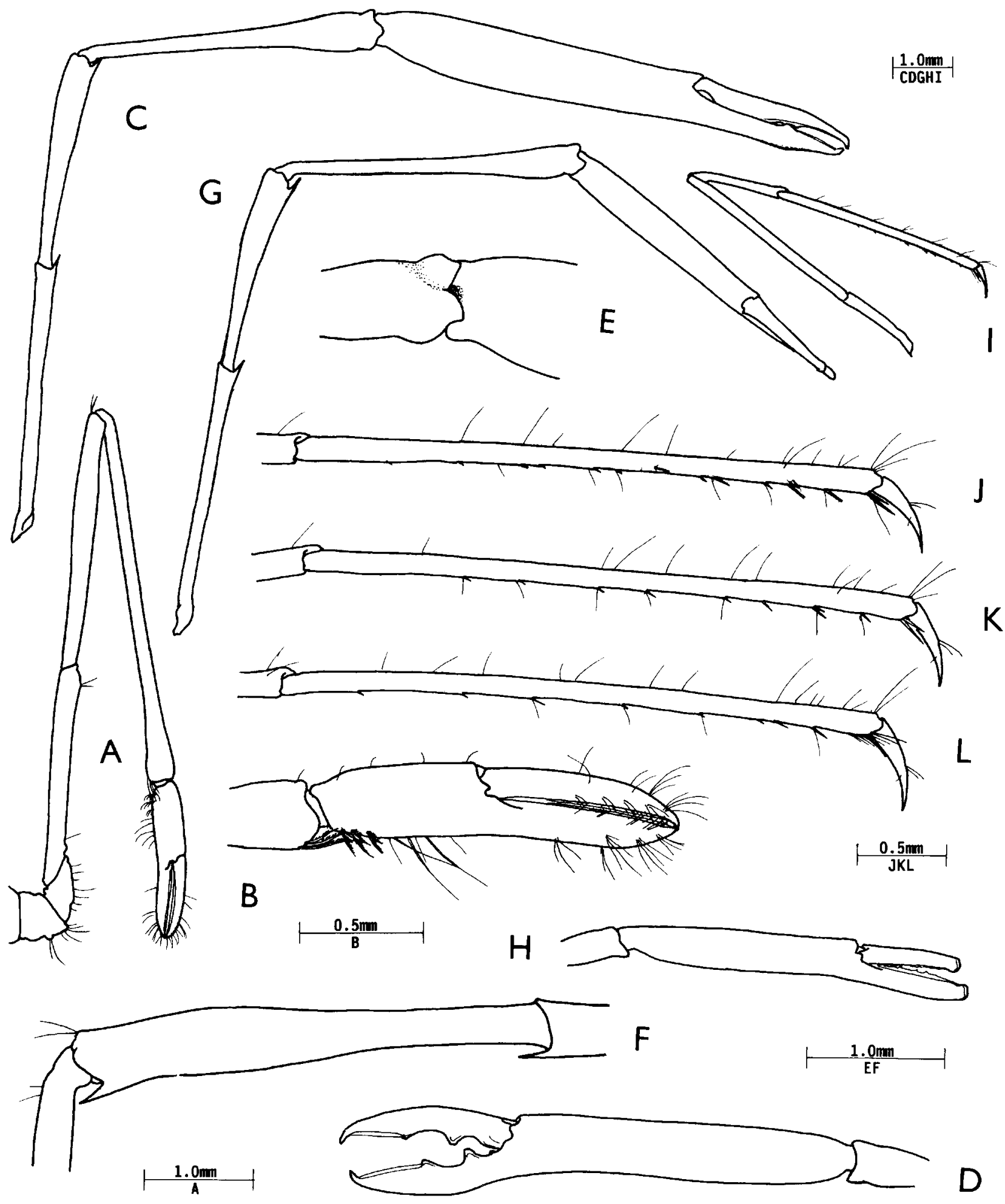

Fig.4. Periclimenes lacertae n.sp., holotype male. A, first pereiopod; B, same, chela; C, major second pereiopod; D, same, chela; E, same, carpopropodal joint, F, same, merus; G, minor second pereiopod; H, same, chela; I, third pereiopod; J, same, propod and dactyl; K, fourth pereiopod, propod and dactyl; L, fifth pereiopod, propod and dactyl. 
slightly narrower proximally; upper flagellum biramous, with rami fused for proximal 20 segments, very long and slender, short ramus, including fused portion, 1.46 times of carapace length, with 2 free segments, with 9 groups of aesthetascs; longer ramus with 6 segments, very slender; lower flagellum about 1.5 times length of short upper ramus length, very slender.

Antenna with stout basicerite, with slender acute distoventral lateral tooth; carpocerite stout, 2.5 times longer than wide; ischiocerite, basicerite normal,

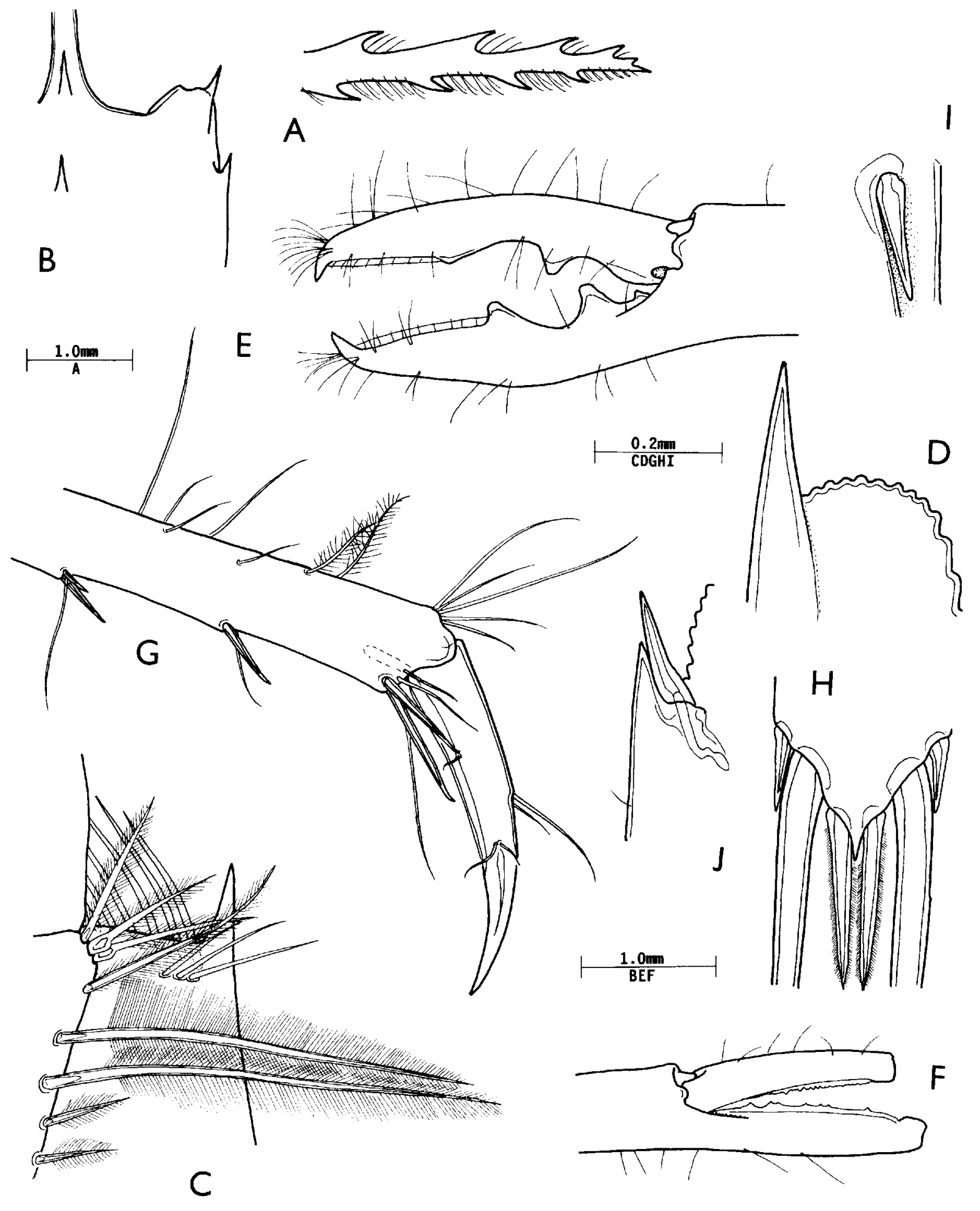

Fig.5. Periclimenes lacertae n.sp., holotype male. A, distal rostrum; B, right orbital region, dorsal; C, antennule, distolateral proximal segment; D, distal scaphocerite; E, major second pereiopod, fingers; F, minor second pereiopod, fingers; $\mathrm{G}$, third pereiopod, distal propod and dactyl; $\mathrm{H}$, telson, posterior spines; I, same, distal spine; $J$, exopod of uropod, distolateral angle. 
flagellum elongate, slender, about 12 times carapace length; scaphocerite reaching to about level of seventh dorsal rostral tooth, about 5.8 times longer than maximal width, at about 0.3 of length, tapering strongly distally, lateral margin concave, with strong acute distal tooth, far exceeding anterior margin of lamella, distal margin of lamella bluntly subrectangular, about 0.38 of maximum width.

Ophthalmic somite without bec ocellaire; epistome unarmed; first to third thoracic sternites broad, unarmed, fourth with slender median process, fifth with transverse carina with deep median notch, sixth to eighth broad, unarmed.

Mandible (right) without palp; corpus stout, molar process expanded distally, obliquely truncate, with 5 stout blunt teeth, with smaller rounded posterior lobe with several short stout setae, incisor process short, stout, with 3 stout acute distal teeth, medial tooth largest, central tooth smallest, medial edge carinate, extending onto molar process; maxillula with slender palp, deeply bilobed distally, upper lobe slender with 4 setae laterally, lower lobe stouter, with small ventral process with single short terminal seta; upper lacinia curved, with about 10 short simple spines distally, with transverse row of short serrulate setae proximally; lower lacinia tapering, with numerous serrulate spiniform setae distally, ventral margin setose, plumose setae proximally; maxilla with simple, tapering palp, basal endite deeply bilobed, lobes subequal, with dense tuft of simple setae distally, coxal endite obsolete, scaphognathite normal, about 3.5 times longer than wide, posterior lobe broad, about 1.4 times longer than wide, anterior lobe tapering distally, 1.5 times longer than wide, medial margin concave; first maxilliped with short, slender, tapering palp with long densely plumose preterminal seta medially, basal endite large, broadly rounded, separated by small notch from coxal endite, large, broadly rounded, medial margin densely setose, coxal endite bilobed, distal lobe rounded, with numerous setae, proximal lobe angular with stout apical seta, several short setae, exopod with welldeveloped flagellum with numerous plumose setae distally, caridean lobe small, epipod large, distal portion tapering, blunt, posterior part truncate; second maxilliped with normal endopod, dactylar segment narrow, densely

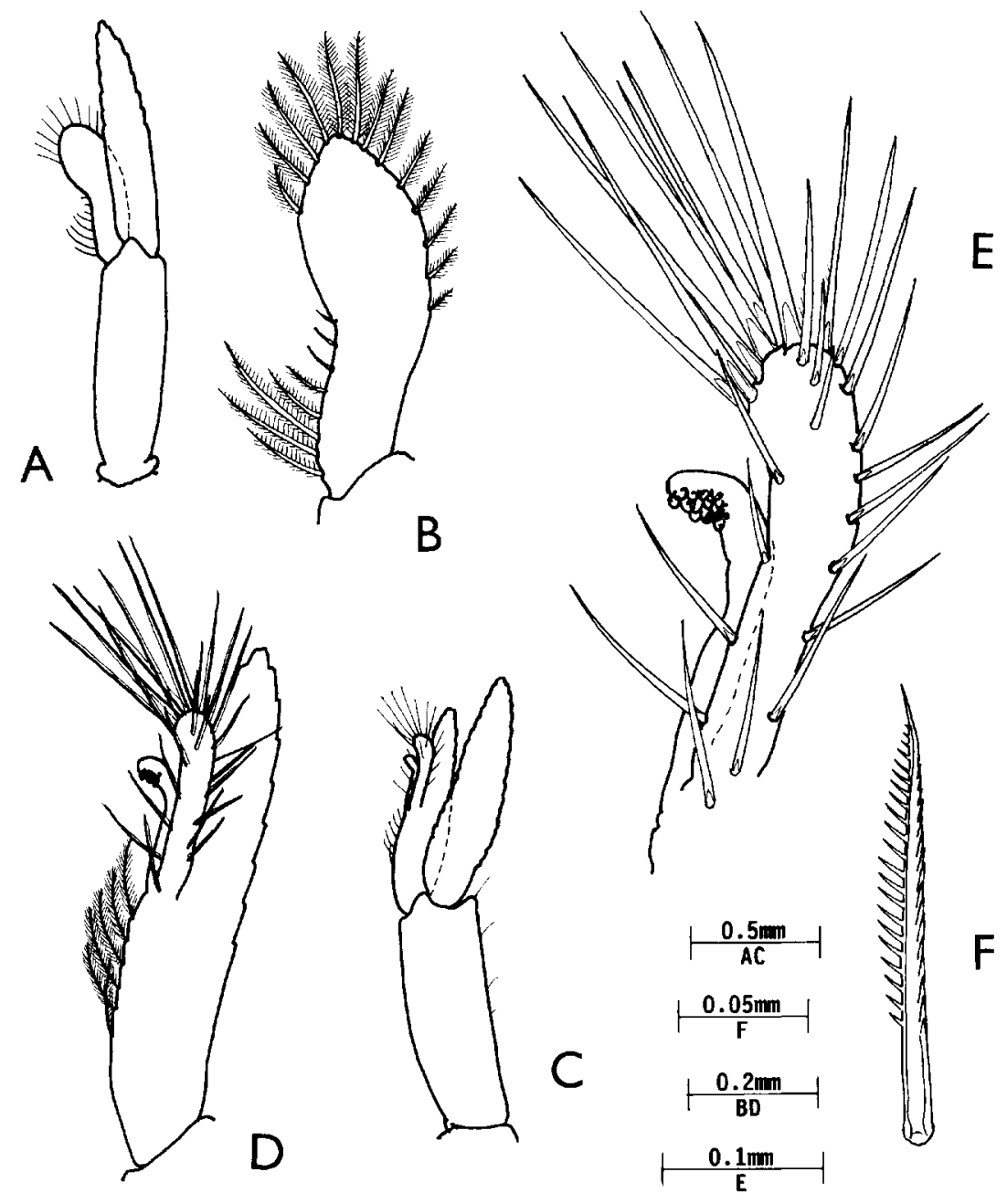

Fig.6. Periclimenes lacertae n.sp., holotype male. A, first pleopod; B, same, endopod; C, second pleopod; D, same, endopod; E, same, appendix masculina and appendix interna; F, third maxilliped, distal segment of endopod, ventral spine. 
margined with short stout, serrulate spines, propodal segment broad, anteromedial margin rounded with about 12 long slender spines, carpus and ischiomerus normal, basis medially excavate, exopod with well-developed flagellum with numerous plumose setae distally, coxa feebly produced medially, non-setose, trapezoid epipod laterally, without podobranch; third maxilliped with endopod slender, exceeding carpocerite by about 0.5 of terminal segment, ischiomerus slender, about 11.0 times longer than distal width, moderately bowed, distal half subcylindrical, with 3 small lateral spines, proximal half slightly swollen, medial margin with sparse long simple setae, penultimate segment 0.75 of proximal segment length, subcylindrical, 9.0 times longer than distal width, with sparse spiniform setae ventrally, distal segment about 0.4 of proximal segment length, tapering distally, 5.0 times longer than proximal width, with stout simple apical spine, sparse groups of stout serrulate spines ventrally, basis not medially produced, sparsely setose, exopod with well developed flagellum with numerous plumose setae distally, coxa feebly produced medially, non-setose, with small rounded lateral plate, without arthrobranch.

First pereiopod long, slender, exceeding carpocerite by about distal tenth of merus; chela with palm subcylindrical, slightly compressed, 2.5 times longer than deep, uniform with 5 groups of short serrulate cleaning setae proximoventrally and several long simple setae, fingers slightly longer than palm with small acute hooked tips, distal 0.8 of cutting edges sharp, entire, simple, feebly laterally situated, with numerous groups of short setae; carpus 2.4 times chela length, proximal 0.8 subuniform, distal 0.2 slightly swollen, about 12.5 times longer than distal width, unarmed, with 4 long serrulate cleaning setae distoventrally; merus about 0.66 of carpus length, 10.0 times longer than maximum width, at about 0.75 of length, unarmed; ischium 0.46 of merus length, about 9.5 times longer than distal width, uniform, unarmed; basis short, unarmed, about 0.16 of carpus length, sparsely setose ventrally; coxa normal, without ventral process.

Second pereiopods very well developed, elongate, slender, unequal, chelae dissimilar; major chela 2.5 times carapace length, palm smooth, subcylindrical, about 5.7 times longer than maximum depth, very feebly swollen proximally, fingers equal to 0.5 of palm length, compressed, expanded centrally, with stout, hooked tips, dactyl about 4.6 times longer than depth at level of major tooth, cutting edge distally entire, sharp, with small tooth at 0.6 of length, separated from major tooth at 0.3 of length by large U-shaped notch, with smaller similar notch proximally, with dactylar fossa present proximally, fixed finger similar, with distal tooth larger, opposing into larger dactylar notch and major tooth into proximal dactylar notch, all teeth distally blunt, major teeth truncate distally; carpus about 0.9 of palm length, proximal two thirds slender, distal third swollen, about 7.5 times longer than distal width, distal margin feebly bilobed dorsally, unarmed; merus 0.64 of palm length, 6.5 times longer than distal width, distally expanded, distal half slightly swollen, 1.8 times wider than proximal width, with large slender acute distoventral tooth; ischium slender, 0.83 of palm length, 12.5 times longer than distal width, slightly tapered proximally, with large slender acute distoventral tooth; basis and coxa normal; minor chela with palm about 1.18 of carapace length, 0.45 of major chela length, palm about 5.5 times longer than deep, smooth, subcylindrical, uniform, fingers damaged, tips lacking, more than 0.5 of palm length, dactyl with sharp cutting edge with numerous irregular very small denticles, fixed finger with fewer, more acute small teeth; carpus 1.36 of palm length, subequal to major carpus length, similar, more slender, about 10.0 times longer than distal width, slightly swollen distally; merus and ischium similar to major chela, subequal, slightly more slender.

Ambulatory pereiopods slender; third pereiopod exceeding carpocerite by distal 0.2 of merus, rostrum by dactyl and distal fourth of propod; dactyl, compressed, curved, without distinctly demarcated unguis, 5.6 times longer than proximal depth, simple, with 1 long, 1 short simple setae at 0.5 of dorsal margin length, pair of sensory setae distomedially and distolaterally, about 0.14 of propod length; propod about 1.06 times carapace length, slender, uniform, unsegmented, about 23.0 times longer than distal width, with pair of strong distoventral spines, 11 spines spaced along ventral margin, distal spines well developed, smaller than distoventral spines, proximal spines small; carpus about 0.39 of propod length, with distinct distodorsal lobe, about 6.5 times longer than distal width, unarmed; merus about 0.92 of propod length, about 17.5 times longer than wide, uniform, unarmed; ischium about 0.33 of propod length, about 6.4 times longer than distal width; basis and coxa without special features; fourth and fifth pereiopods similar to third, propod of fourth slightly longer, 1.06 times third propod length, slightly more feebly spinulate ventrally, fifth propod with medial distoventral spine only, with 4 pairs of distolateral cleaning setae.

First pleopod with basipodite 3.5 times longer than broad; exopod subequal to basipodite length, 5.5 times longer than proximal width; endopod about 0.58 of exopod length, 4.0 times longer than central width, distal half expanded, proximal half of medial margin with few serrulate spiniform setae proximally, 3 short simple spines distally, distal fourth of medial margin and distal half of lateral border with 13 short plumose setae. Second pleopod with basipodite 3.0 times longer than broad, subequal to first basipodite length, exopod subequal to basipodite length, 4.0 times longer than central width; endopod about 0.88 of exopod length, about 4.2 times longer than central width, with appendices at 0.5 of medial margin length; appendix masculina about 0.3 of endopod length, subcylindrical, about 5.5 times longer than central width, slightly swollen and medially curved, with about 10 short slender spines along lateral margin, 4 along medial margin, 3 distoventrally, 8 stout slender simple spines distally, longest about 0.8 of corpus length, appendix interna about 0.75 of appendix masculina length, with few distal cincinnuli. 
Uropod with protopodite posterolaterally acute; exopod about 2.6 times longer than wide, extending well beyond tip of telson, lateral margin straight, unarmed, sparsely setose, with small acute distal tooth with larger acute mobile spine medially, diaeresis obsolete; endopod 0.91 of exopod length, about 3.15 times longer than broad.

Measurements (mm). Total length (approx.) 21.0; carapace and rostrum 10.2; carapace 3.6 ; major second pereiopod chela 8.8 ; minor second pereiopod chela $6.0+$.

Type. The single male specimen is designated as holotype and deposited in the AM collection, registration number P39299.

Colouration. No data.

Etymology. From lacerta (latin), a lizard, in reference to locality of capture, Lizard Island.

Systematic position. Periclimenes lacertae is most closely related to $P$. tenuipes Borradaile, 1898, first reported from New Britain and subsequently widely recorded throughout most of the Indo-west Pacific region, and which itself occupies a rather isolated position in relation to other species of the genus. Both species are members of the " $P$. grandis species group" sensu latu, with a well-developed, finger-like median process on the fourth thoracic sternite and have welldeveloped meral spines on the second pereiopods, lack supraorbital spines and have slender ambulatory pereiopods with slender, not strongly curved dactyls. Periclimenes lacertae is immediately distinguished from all related species by the presence of slender distoventral ischial tooth on the second pereiopods. Other features in which it differs from $P$. tenuipes are that the rostrum is straight and horizontal, not sinuous and up-curved, with a similar dentition of 10/6, compared with 8-11/ 6-9 in $P$. tenuipes. In $P$. tenuipes, the ambulatory propods are reported to be segmented and devoid of spines (Kemp, 1922), but show no signs of segmentation and are distinctly spinose in $P$. lacertae. The pleuron of the fourth abdominal somite appears more rounded, less angular, in $P$. lacertae, and that of the fifth, more acutely pointed than in Kemp's figure (pl.8 fig.11).

Remarks. Periclimenes ischiospinosus Bruce, known only from two specimens from New Caledonia (Bruce, 1991), is the only other Indo-west Pacific species of Periclimenes to have an ischial spine on the second pereiopods. In its general morphology it shows a close similarity to $P$. lacertae but does not belong to the " $P$. grandis group", and lacks a median process on the fourth thoracic sternite. Both specimens of $P$. ischiospinosus have damaged rostra and detailed comparison is therefore not possible. $P$. ischiospinosus also occurs in deeper water, from $50 \mathrm{~m}$.

A key to the species of the " $P$. grandis group" has been provided by Bruce (1987). Periclimenes lacertae can be readily incorporated by means of the following couplets:

12. Rostrum greatly exceeding scaphocerite ........ 12a

Rostrum subequal to scaphocerite

12a. Second pereiopods with ischium distoventrally unarmed. rostrum sinuous, upcurved, ambulatory propods segmented, non-spinulate; R. 1+8-11/6-9 $P$. tenuipes Borradaile

Second pereiopods with strong distoventral ischial tooth; rostrum straight, horizontal; ambulatory propods not segmented, spinulate; R. $1+10 / 6$

$P$. lacertae n.sp.

\section{Periclimenes priodactylus n.sp.}

Figs 1, 7-11

Material examined. 1 male, stn Qld-320, Lizard Island, Queensland, $14^{\circ} 40^{\prime} \mathrm{S} 145^{\circ} 28^{\prime} \mathrm{E}$, northern entrance to Blue Lagoon, Lizard Island, $3.5 \mathrm{~m}$, trap, 6-7 June 1989, coll. S.J. Keable, D.J. Townsend.

Description. Very small-sized shrimp, subcylindrical body form.

Carapace smooth, glabrous, with well-developed, compressed rostrum, subequal to carapace length, slightly exceeding antennular peduncles, horizontal, distally acute tip slightly upturned, well-developed feebly convex dorsal carina with 7 acute teeth, all anterior to posterior orbital margin, regularly spaced, size decreasing slightly distally, lateral carinae well developed, broadening posteriorly, ventral carina feebly developed, ventral margin straight, non-setose, with single very small acute tooth distally, below seventh dorsal tooth; epigastric and supraorbital spines absent, with small postorbital tubercle, orbital notch broad, orbit obsolete, inferior orbital angle feebly produced, broadly rounded, antennal spine small, submarginal, hepatic spine small, slender, ? mobile, slightly below level of antennal spine, anterolateral branchiostegite not produced, broadly rounded.

Abdomen smooth, glabrous, third segment feebly posterodorsally produced, sixth segment about 2.5 times longer than fifth, compressed, 1.5 times longer than deep, about 0.5 of carapace length, posteroventral angle slightly produced, subacute, posterolateral angle blunt; pleura of first 3 segments broadly rounded, fifth and sixth rounded, slightly posteriorly produced. Telson about 0.7 of carapace length, 3.0 times longer than anterior width, lateral margins sublinear, convergent, with 2 pairs of small marginal dorsal spines, about 0.045 of telson length, at 0.6 and 0.8 of telson length, posterior margin about 0.4 of anterior width, feebly angular, with median process, with 3 pairs of spines, lateral spines small, subequal to dorsal spines, intermediate spines 
robust, about 0.16 of telson length, 4.5 times longer than wide, submedian spines well developed, very slender distally, 0.78 of intermediate spine length, distally densely setulose.

Antennule with peduncle slightly exceeded by rostrum, far exceeded by scaphocerite, proximal segment about 2.5 times longer than central width, medial margin with ventromedial tooth, stylocerite short, broad, acute, reaching about 0.4 of segment length, slightly laterally projecting, statocyst normally developed, with granular statolith; intermediate and distal segments short, subequal, together subequal to 0.45 of proximal segment length; upper flagellum small, short, biramous, proximal 2 segments fused, shorter free ramus 2 segmented, longer ramus 4 segmented, with 5 groups of aesthetascs; lower flagellum short, 6 segmented, subequal to peduncle length.

Antenna with basicerite unarmed; carpocerite short, stout, about 1.6 times longer than distal width, 0.25 of scaphocerite length, flagellum stout, robust, about 2.0 times carapace length, about 10 segments, obscurely segmented proximally; scaphocerite about 0.7 of carapace length, distinctly exceeding rostrum and antennular peduncles, about 3.3 times longer than central width, broad, distal lamella bluntly angular, lateral margin feebly concave, with slender distal tooth, far exceeded by lamella.

Eye large, with transverse hemispherical cornea, diameter about 0.33 of carapace length, with small dorsal accessary pigment spot; stalk about 1.2 times wider than corneal diameter, 1.1 times wider than length.

Ophthalmic segment without bec ocellaire, with conspicuous black pigment spot; epistome unarmed, fourth thoracic sternite without slender median process, posterior segments unarmed (?).

Mandible (right) with corpus moderately robust, without palp, molar process stout, with conspicuous blunt teeth distally, left molar process with row of stout distal spines, incisor process well developed, tapering distally, with distal margin transverse with 3 acute teeth, central tooth smaller than medial and lateral teeth; maxillula with short, stout, feebly bilobed palp, upper lobe small, lower lobe with short simple seta, upper lacinia normal, with 7 short, simple distal spines in 2 rows, with sparse short setulose setae, lower lacinia short, stout, tapering, blunt, with few serrulate distal setae; maxilla with slender simple tapering palp with short plumose setae proximolaterally, basal endite well developed, bilobed, lobes slender, with 4 simple setae distally, coxal endite obsolete, medial margin short, convex, scaphognathite well developed, about 3.0 times longer than wide, posterior lobe long, narrow, 3.0 times longer than anterior width, 0.33 of scaphocerite length, anterior lobe broad, about 1.3 times longer than wide, whole margin fringed with short, very stout, plumose setae; first maxilliped with slender simple, non-setose tapering palp, basal endite large, broad, distally rounded, medial margin straight, sparsely setose, with longer, feebly denticulate setae distally, shorter, sparsely denticulate setae proximally, coxal endite reduced, small, rounded, with 3 short feebly denticulate setae, 1 long, more strongly denticulate seta, exopod with well-developed flagellum, with 4 plumose setae distally, caridean lobe narrow, epipod lost in dissection (?); second maxilliped with normal endopod, dactylar segment about 2.8 times longer than broad, with few stout spines medially, strongly denticulate distally, propodal segment broad, with few short denticulate setae distomedially, sparse long feebly denticulate spiniform setae ventrally, carpus and merus normal, ischiomerus feebly excavate distomedially, exopod with well-developed flagellum, with 4 plumose setae distally, coxa feebly produced medially, with single short, simple seta, with small epipod laterally, without podobranch; third maxilliped with endopod slender, simple, reaching to about proximal end of carpocerite, ischiomerus and basis fused, junction

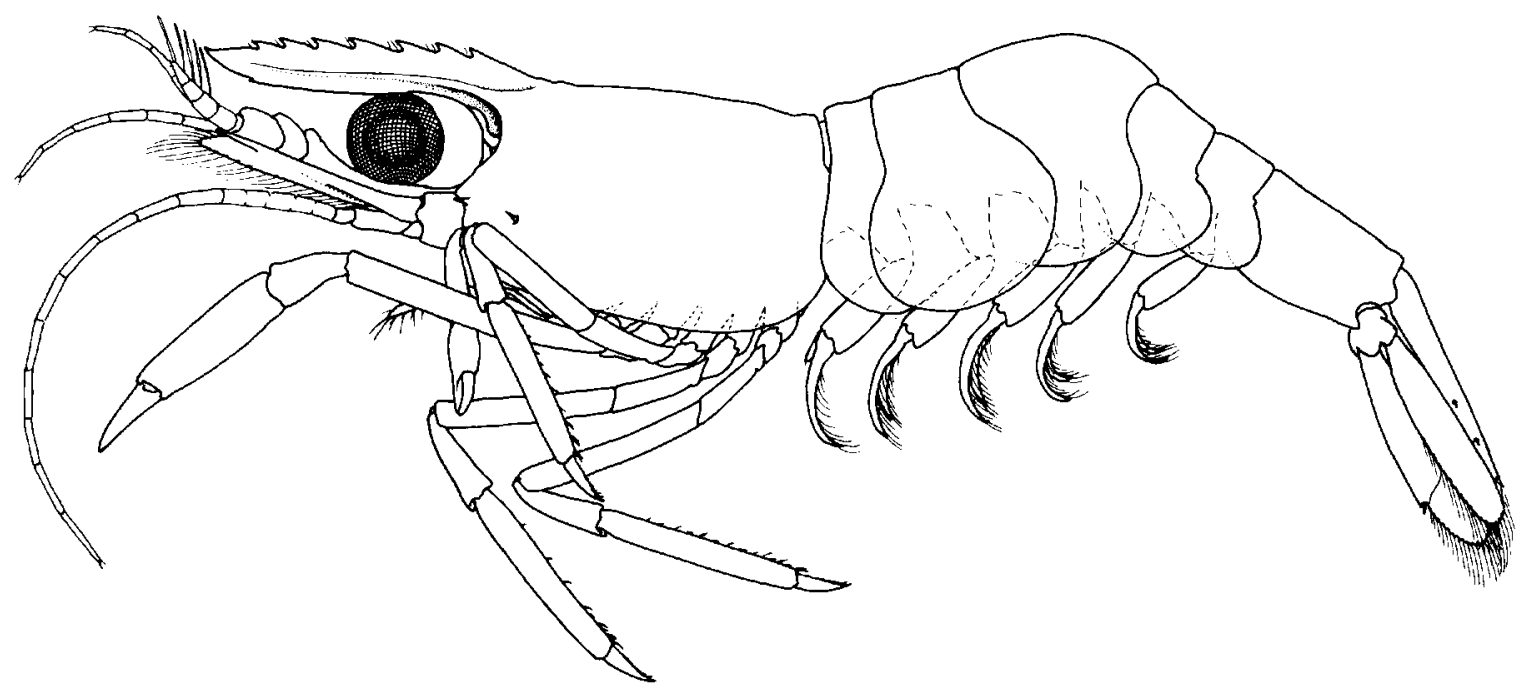

Fig.7. Periclimenes priodactylus n.sp., holotype male, Lizard Island, Queensland, scale bar in millimetres. 
indicated by small median notch, combined segment bowed, about 4.8 times longer than distal width, slightly broadened distally, with basal region expanded, medially broadly convex, medial margin with sparse short simple setae, penultimate segment about 0.4 of proximal segment length, 2.8 times longer than wide, subuniform, with sparse long, feebly denticulate spiniform setae distally, with few similar setae ventrally, exopod with well-developed flagellum with 4 plumose setae distally, coxa with small angular medial process, with oval lateral plate, with vestigial arthrobranchial tubercle.

First pereiopod moderately short, stout, robust, exceeding carpocerite by length of chela; chela with palm subcylindrical, feebly compressed, slightly expanded distally, 1.5 times longer than distal width, with 2 serrulate cleaning setae proximally; fingers with strongly subspatulate cutting edges, lateral, entire, tips stout, moderately hooked, dactyl about 1.1 times palm length, 3.0 times longer than proximal depth, fixed fingers similar, carpus stout, about 0.58 chela length, 2.0 times longer than proximal width, slightly narrowed proximally, ventrally unarmed; merus about 0.8 of chela length, 1.5 times palm length, 5.0 times longer than wide, uniform, unarmed; ischium about 0.45 of chela

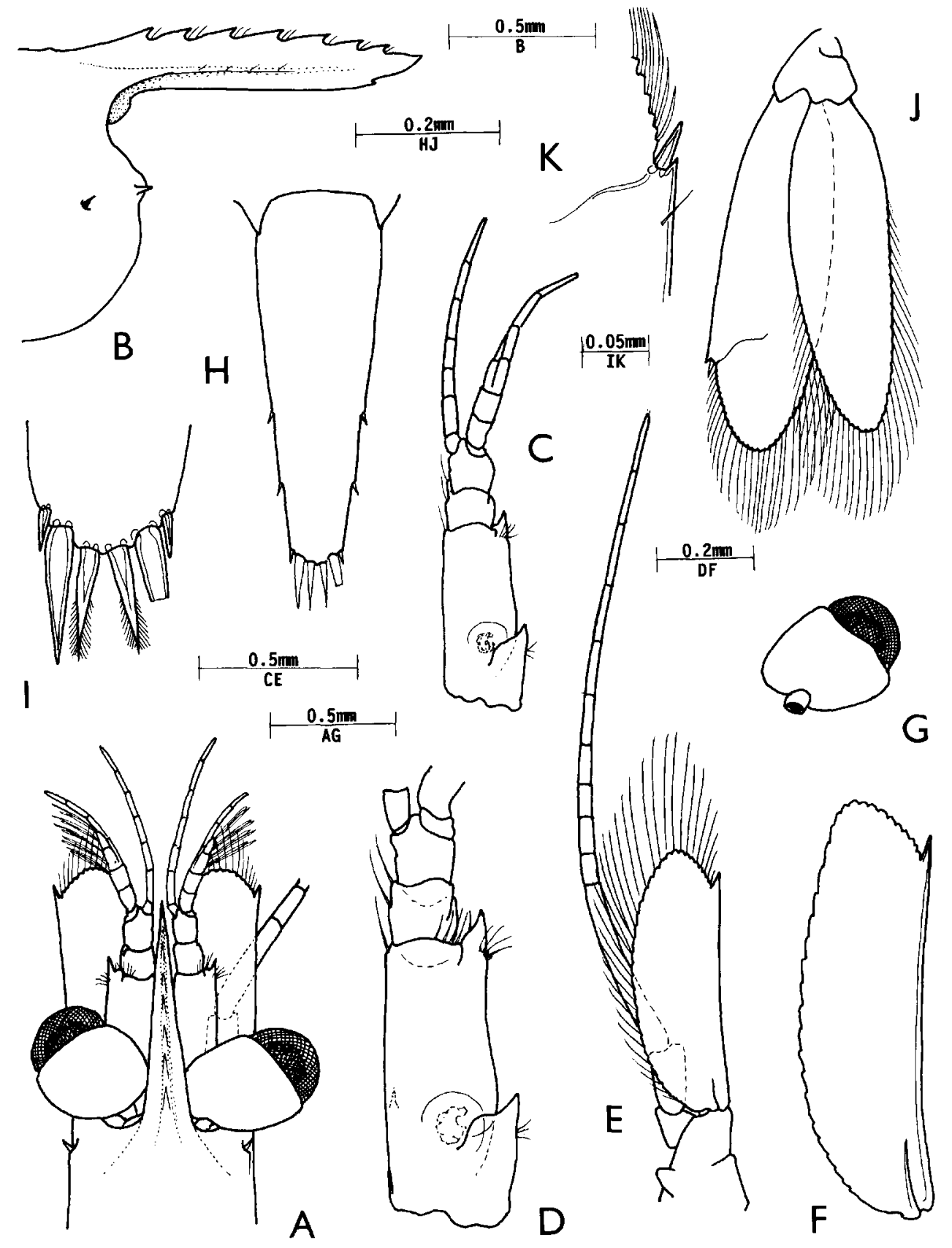

Fig.8. Periclimenes priodactylus n.sp., holotype male. A, anterior carapace, rostrum, eyes and antennae; $\mathrm{B}$, anterior carapace and rostrum, lateral; $\mathrm{C}$, antennule; $\mathrm{D}$, same, peduncle; $\mathrm{E}$, antenna, ventral; $\mathrm{F}$, scaphocerite; $\mathrm{G}$, eye; H, telson; I, same, posterior spines; J, uropod. 
length, 2.2 times longer than distal width, obliquely articulated with basis, unarmed; basis about 0.7 of ischial length, unarmed; coxa with small setose ventral process.

Second pereiopods well developed, subequal, similar; chelae about 0.72 of carapace length, palm subcylindrical, smooth, about 2.75 times longer than distal depth, slightly compressed and broadened distally, dactyl about 0.7 of palm length, 3.3 times longer than proximal depth, tapering to stout feebly hooked, blunt tip, cutting edge lateral, distal half sharp, unarmed; carpus short, stout, about 0.45 of palm length, 1.4 times longer than distal width, slightly excavate distally, tapered proximally, unarmed; merus about 0.8 of palm length, 3.5 times longer than central depth, uniform, distoventral angle unarmed, bluntly rectangular; ischium subequal to meral length, about 3.4 times longer than distal width, tapered proximally, obliquely articulated with basis, unarmed; basis about 0.3 of palm length; coxa about 0.25 of palm length, both without special features.

Ambulatory pereiopods moderately robust; third pereiopod exceeding carpocerite by dactyl and most of propod, dactyl compressed, with unguis distinctly demarcated, slender, about 0.3 of corpus length, 5.5 times longer than proximal depth, tapering distally, dorsal margin convex, ventral margin straight, with welldeveloped distal accessory tooth, major part with series of very acute, compressed serrations, distally inclined, of increasing size distally, distolaterally with several

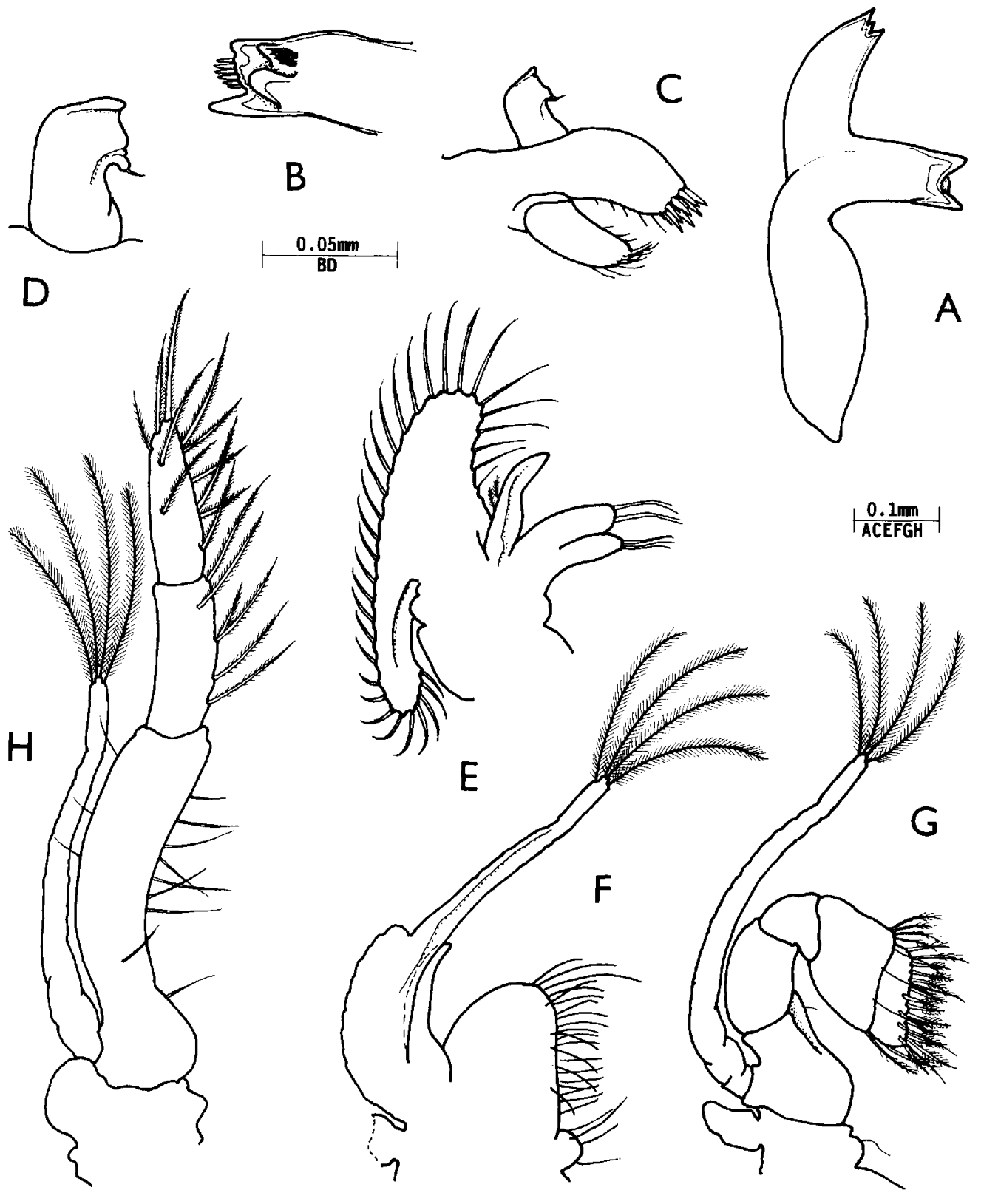

Fig.9. Periclimenes priodactylus n.sp., holotype male. A, mandible; B, same, molar process; C, maxillula; D, same, palp; E, maxilla; F, first maxilliped; G, second maxilliped; $H$, third maxilliped. 
long simple setae; propod about 0.6 of carapace length, 3.5 times dactyl length, 6.0 times longer than central depth, distal half slightly tapered, with 3 distoventral spines, with single distolateral spine, 2 pairs of spines with offset medial and lateral ventral rows of 3 and 4 spines more proximally, spines sinuous, distoventrally denticulate, suberect posteriorly, distally inclined distally; carpus about 0.43 of propod length, 2.4 times longer than distal width, with strong distodorsal lobe, unarmed; merus about 0.85 of propod length, 5.0 times longer than deep, uniform, unarmed, distoventral angle bluntly rectangular; ischium about 0.5 of propod length, 3.0 times longer than distal width, unarmed; basis without special features; coxa with small setose ventral process. Fourth pereiopod similar to third, propod about 1.1 times third propod length, 6.0 times longer than deep, with distoventral pair of spines, medial and lateral ventral rows with 7 and 3 spines respectively. Fifth pereiopod similar to fourth.

First pleopod with basipodite 2.2 times longer than wide, exopod 1.2 times basipodite length, 4.4 times longer than wide, endopod about 0.36 of exopod length, 2.3 times longer than proximal width, medial margin straight, with single small spinule proximally, lateral margin convex, distally convergent to rounded tip, nonsetose. Second pleopod with basipodite about 1.1 times first basipodite length, 2.3 times longer than wide, exopod 1.1 times basipodite length, 3.5 times longer than broad, endopod about 0.9 of exopod length, 3.8 times longer than wide, appendix masculina at 0.35 of endopod
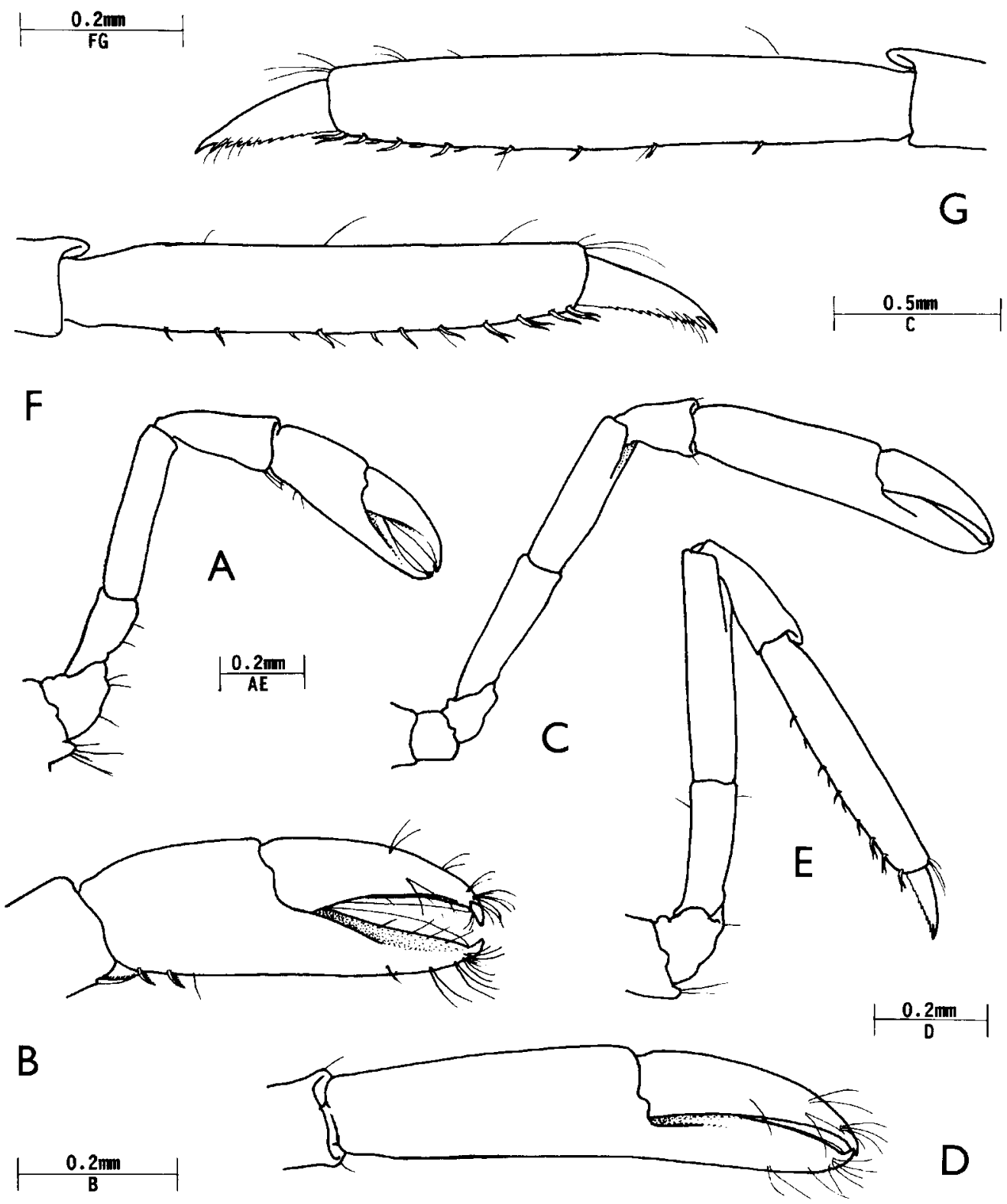

Fig.10. Periclimenes priodactylus n.sp., holotype male. A, first pereiopod; B, same, chela; C, second pereiopod; D, same, chela; E, third pereiopod; F, same, propod and dactyl; G, fifth pereiopod, propod and dactyl. 
length, 0.45 of endopod length, distally swollen, cincinnuli not discernible, appendix masculina at 0.45 of endopod length, short, 0.22 of endopod length, subcylindrical, centrally swollen, 3.0 times longer than wide, with single long, simple terminal spiniform seta, 1.4 times corpus length, and shorter subterminal distolateral spiniform seta.

Uropod with protopodite distolaterally unarmed; exopod distinctly exceeding telson, 3.2 times longer than broad, lateral margin convex proximally, distally straight, with small acute distal tooth, with larger mobile spine medially, diaeresis feebly indicated; endopod about 0.9 of exopod length, 3.2 times longer than wide.

Measurements (mm). Total length (approx.) 4.75; carapace and rostrum 2.0; carapace 1.1 ; second pereiopod chela 0.8 .
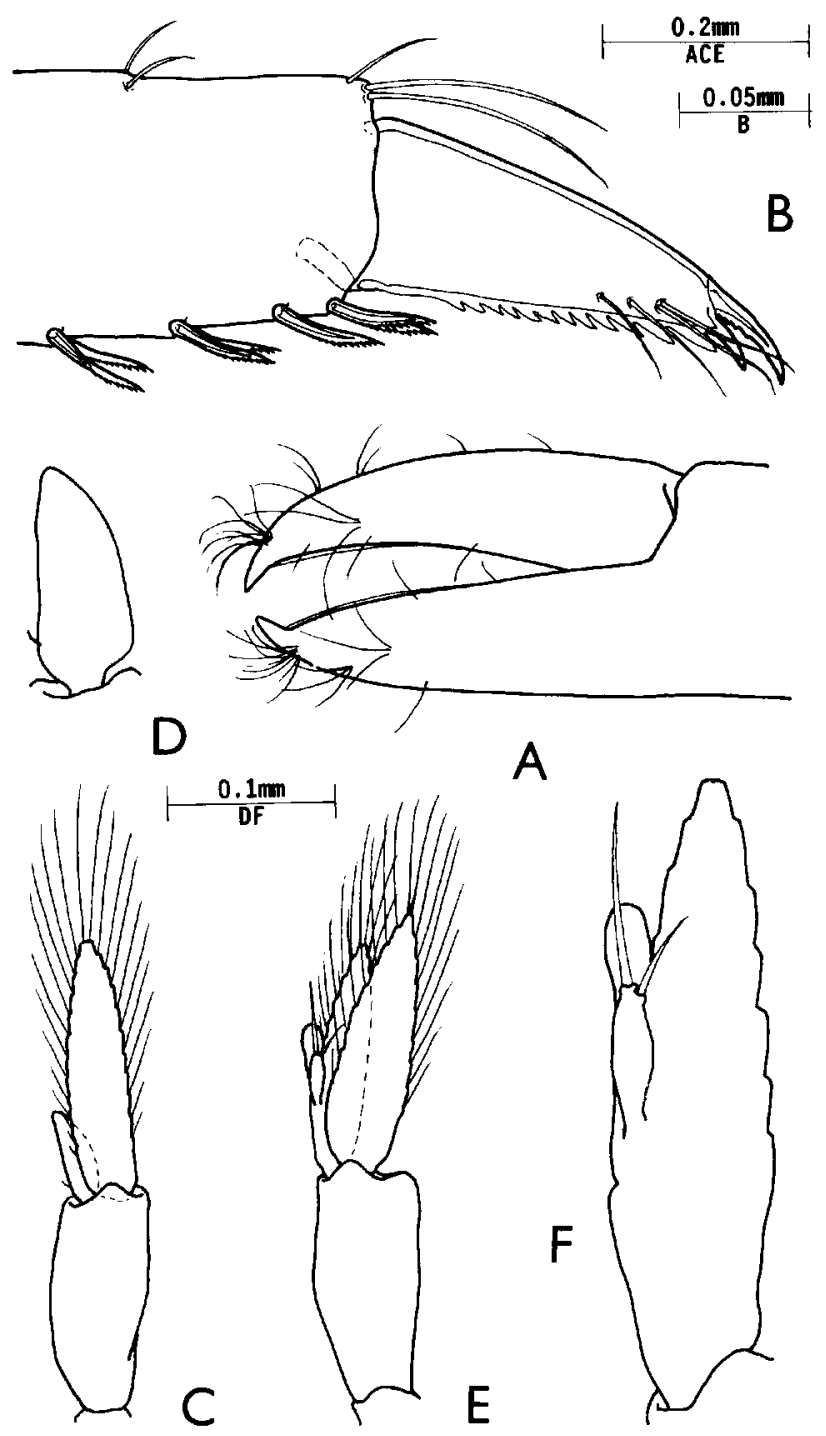

Fig.11. Periclimenes priodactylus n.sp., holotype male. A, second pereiopod, fingers; B, third pereiopod, dactyl and distal propod; C, first pleopod; D, same, endopod; E, second pleopod; F, same, endopod.
Type. The single male specimen is the holotype and is deposited in the AM collection, registration number P39435.

Host, colouration. No data.

Etymology. From prion (Greek) a saw; daktylos (Greek) finger, with reference to the morphology of the ambulatory dactyl.

Systematic position. Periclimenes priodactylus does not appear to be closely related to any of the so far described species of Periclimenes. The subspatulate fingers of the first pereiopod suggest an affinity to $P$. imperator Bruce, $P$. rex Kemp, $P$. soror Nobili or $P$. pectiniferus Holthuis but these all have the cutting edges of the first pereiopod fingers finely pectinate, and the dactyls of the ambulatory pereiopods are biunguiculate or simple, without ventral serrations. The only Indo-west Pacific species of Periclimenes with ventral serrations on the ventral border of the ambulatory dactyl corpus is $P$. signatus Kemp, 1925, of unknown associations, and known only from the male holotype specimen from the Andaman Islands. Periclimenes signatus lacks a subspatulate chela on the first pereiopods, has a rostral dentition of $10 / 1$, with the first tooth posterior to the orbital margin, and a well-developed ventral tooth at half the ventral margin length, scaphocerite with distolateral tooth far exceeding lamella, antennal spine postmarginal, hepatic spine on same level as antennal, and fingers of second pereiopod strongly dentate. The ambulatory propods and dactyls show distinct similarities to $P$. priodactylus, with the dactyl biunguiculate, the ventral margin of the corpus microscopically serrate, the ventral margin of the propod densely spinulose, with about 24 spines in a single row illustrated in this position by Kemp (1925: fig.17d), and apparently all non-denticulate. The dactyl is only about 0.16 of the propod length and appears feebly serrated along the dorsal margin of the corpus or may have had a series of setae in this position. Periclimenes signatus is also a very small species, the specimen having a length of $11 \mathrm{~mm}$, however, still distinctly larger than $P$. priodactylus.

Remarks. The specimen of $P$. priodactylus was caught by means of a small baited trap set ovemight on the sandy lagoon floor, with numerous conical sand mounds. The traps have a funnel entrance of only about $1 \mathrm{~cm}$ and are baited with meat fragments. No echinoderms were captured.

Some recently described deep-water pontoniine shrimps from the North Atlantic Ocean, Periclimenes milleri and $P$. ingressicolombi (Bruce 1987a; Berggren \& Svane, 1989) have ambulatory pereiopods resembling $P$. priodactylus, with numerous acute serrations along the ventral margin of the dactyl and the ventral propods with numerous denticulate spines. These species, observed and captured from submersibles, are known to associate with echinoid hosts, suggesting that $P$. priodactylus (and $P$. signatus) may be involved in similar 
associations. Allopontonia iaini Bruce also has a series of fine serrations along the ventral margin of the ambulatory dactyls and is known to be an echinoid associate, its hosts being the temnopleurid urchins Salmaciella dussumieri and Salmacis sphaeroides and also diadematid urchins of the genus Asthenosoma.

Periclimenes priodactylus is noteworthy for its minute size, about the same as many first post-larval stage pontoniine shrimps, and its juvenile appearance is enhanced by the relatively large size of the eye. The presence of the appendix masculina shows that the specimen is not a juvenile and must represent a species that matures at a very small size. Other very small pontoniine shrimps have been reported: Tectopontonia maziwiae, ovigerous female, total length $8.0 \mathrm{~mm}$ (Bruce, 1973); Typton nanus, female $3.75 \mathrm{~mm}$ (Bruce, 1988)

\section{Periclimenes denticulatus Nobili, 1906}

Figs $12-14$

\section{Restricted synonymy}

Periclimenes Petitthouarsi var. denticulata Nobili, 1906: 257 258.-Nobili, 1907: 358-359

Periclimenes (Falciger) denticulatus-Borradaile, 1917: 368 , 372.

Periclimenes (Ancylocaris) denticulatus.-Kemp, 1922: 170 , 197.

Periclimenes (Harpilius) denticulatus.-Holthuis, 1952: 11. Palaemonella denticulata.-Holthuis, 1953: 55.

Periclimenes identiculatus.-Bruce, 1979: 230-231 (erroneous spelling for ? denticulatus).

Periclimenes denticulatus.-Devaney \& Bruce, 1987: 223, 230.

Material examined. 1 male, stn Qld-135, off Coconut Beach, Lizard Island, $32 \mathrm{~m}$, trap, on sand with Halimeda, 1112 Jan. 1989, coll. J.K. Lowry and S.J. Keable, AM P39287 (partim).

Remarks. The single example lacks both second pereiopods and can not therefore be identified with absolute certainty. Periclimenes denticulatus is a little known species that has not yet been adequately described or illustrated, but the holotype specimen, unfortunately now in poor condition, is held in the collection of the Muséum National d'Histoire Naturelle, Paris (Na. 1944, CL. $3.0 \mathrm{~mm}$ ) and, through the kindness of Prof. Jacques Forest, has been re-examined.

The Lizard Island specimen has the rostrum about 1.3 times its carapace length, moderately up-curved, with six acute dorsal teeth and three similar ventral teeth. The carapace has an epigastric tooth, a large marginal antennal spine and a smaller hepatic spine at a slightly lower level. The cornea of the eye is large and globular. The mandible bears a very small singlesegmented palp, flattened, subcircular with two short simple lateral setae. The molar process is robust with two stout acute teeth distodorsally, with a broad posterior lobe, large, fringed with flattened setae. The incisor process is well developed, transversely truncate distally with three acute teeth, the central tooth smaller than the outer teeth, and a small preterminal medial tooth. The maxillula has a bilobed palp, the upper lobe with three short simple setae and the lower lobe with a small setose ventral tubercle. The upper lacinia is moderately broad, tapering, with about ten short simple spines distally and numerous short setae ventrally. The lower lacinia is short and broad, with several long spiniform setae distally and numerous setae ventrally. The maxilla has a simple palp, basal endite bilobed, coxal endite obsolete, scaphognathite short, posterior lobe narrow. The first maxilliped has a setiferous palp, basal endite broad, densely setose, coxal endite distinct, exopod with small caridean lobe, flagellum with numerous plumose setae distally and the epipod large and simple. The second maxilliped has a normal endopod, the flagellum of the exopod with numerous plumose setae distally: the epipod was probably lost in dissection. The third maxillipeds have a slender endopod, with the ischiomerus and basis fused, but distinctly demarcated. The ischiomerus is sparsely setose medially, with a single large fusiform seta at about 0.5 of the combined segment length, about $0.25 \mathrm{~mm}$ in length, 5.75 longer than wide. A small arthrobranch, with rudimentary lamellae, is present. The fourth thoracic sternite has a small triangular median process, the fifth has a pair of long acute submedian teeth, other segments are unarmed. The first pereiopod is slender, with the chela about 0.55 of the carpus length. The fingers are about 1.5 times the palm length, deeply subspatulate with strongly denticulate lateral cutting edges. The tip of the dactyl bears a single stout tooth, with a thin, feebly crenulate transparent lamella medially. The tip of the fixed finger bears a pair of similar teeth with an acute lamellar process medially. The ambulatory propods are moderately slender, the third propod is about 16.5 times longer than wide, with a pair of long distovental spines and five smaller ventral spines. The dactylus is about 0.23 of the propod length, compressed, with unguis not distinctly demarcated, about 4.2 times longer than proximal width, with a long and a short seta at about 0.5 of the dorsal margin length and a pair of distolateral sensory setae. The first pleopod has the endopod about 0.9 of the exopod length, about 5.8 times longer than proximal width, slightly expanded distally, proximal fourth of medial margin with four long sparsely setulose setae, central half with six fine simple setae, with 11 short plumose setae round the distal margin. The endopod of the second pleopod bears appendices at about 0.5 of the medial margin length, the appendix masculina distinctly exceeding the appendix interna but not the tip of the endopod. The corpus is subcylindrical about 4.5 times longer than wide, 0.33 of the endopod length, with three stout spines distally, the longest spine almost subequal to the corpus length, finely serrulate along the lateral margins, with two distolateral, and three distomedial simple setae.

The holotype specimen lacks all mouthparts, so it cannot be determined if the unusual fusiform setae on the ischiomerus of the third maxillipeds of the Lizard 
Island specimen were present or not. However, similar setac, which have not been reported in any other pontoniine shrimp, were noted as occurring on the distoventral merus of the second pereiopods. The exact similarity of left and right maxillipeds in the Lizard Island specimen, supports the view that their presence is a normal feature and not due to damage or injury.

The specimens of $P$. denticulatus reported from

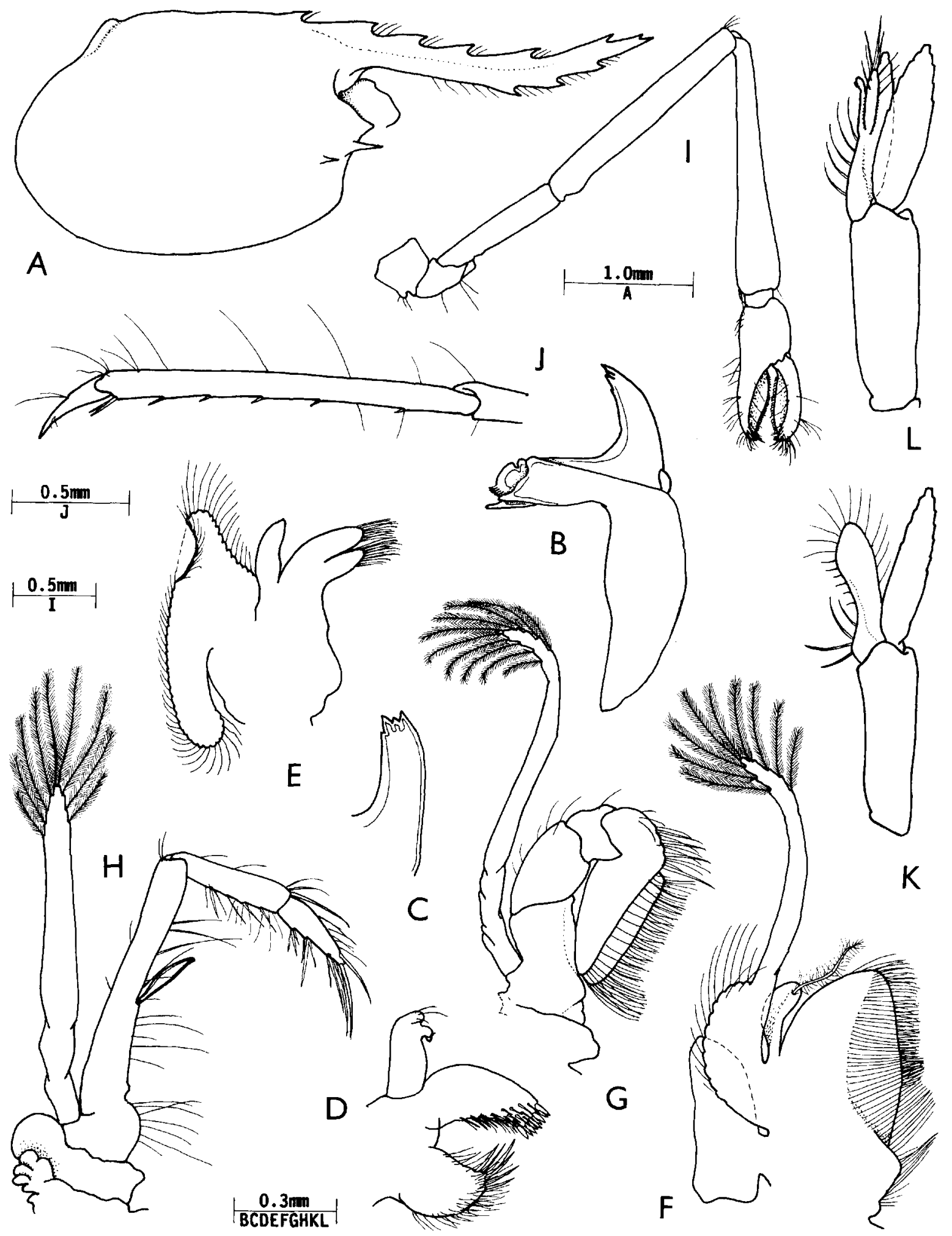

Fig.12. Periclimenes denticulatus Nobili, Lizard Island, male. A, carapace and rostrum; B, mandible (right); C, same, incisor process; D, maxillula; E, maxilla; F, first maxilliped; G, second maxilliped; H, third maxilliped; I, first pereiopod; J, third pereiopod, propod and dactyl; K, first pleopod; L, second pleopod. 
Eniwetak Atoll, (Devaney \& Bruce, 1987) have also been re-examined and found to be closely similar to the present specimen, except that one of the third maxillipeds bears two fusiform setae and the other three. As in the Lizard Island specimen, these setae are about 0.20 to $0.24 \mathrm{~mm}$ long. The distolateral merus of the third maxilliped also bears three small mobile spines. The two specimens, which are macerated, are in poor condition (male CL $2.1 \mathrm{~mm}, \mathrm{R} .1+7 / 3$; female CL $2.1 \mathrm{~mm}, \mathrm{R}$. $1+7 / 3$ ). The female has both second pereiopods, which are similar, subequal, with three strong acute spines on the distal margin of the carpus, with three distoventral spines and a preterminal distomedial spine on the merus. The merus does not show any of the fusiform setae as found in the holotype, but these were noted in that specimen as very easily detached. The distoventral angle of the merus is unarmed. The chela is slender, with the palm subcylindrical, feebly compressed, smooth, about 0.18 of the carpus length, 4.6 times longer than wide; the fingers are slender, with acute moderately hooked tips. The dactylus is about 8.5 times longer than its proximal width, with a small proximal fossa medially, the distal cutting edge entire, the proximal cutting edge with seven to eight low teeth, without any trace of sound-

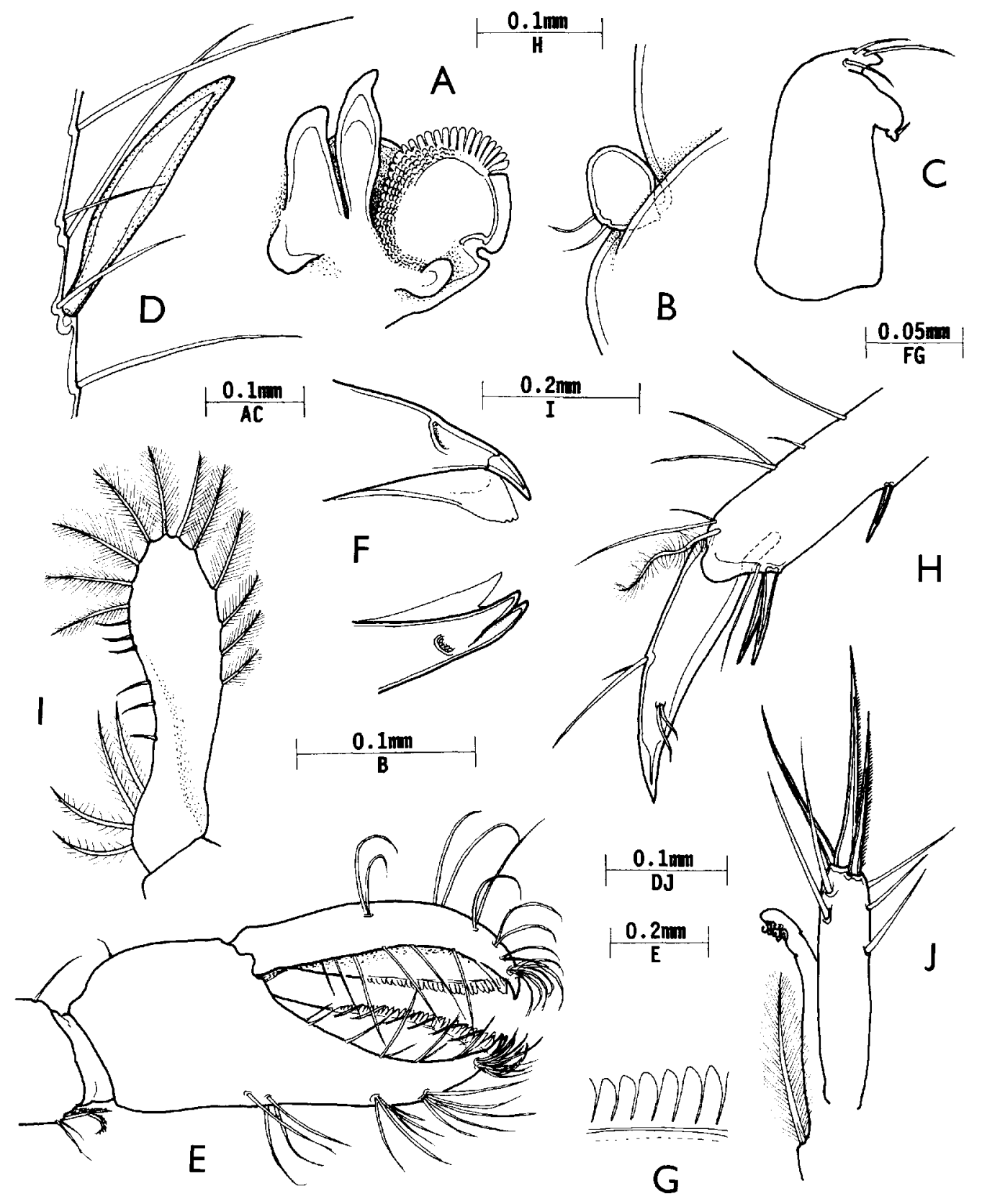

Fig.13. Periclimenes denticulatus Nobili, Lizard Island. A, mandible, right molar process; B, same, palp; C, maxillula, palp; D, third maxilliped, ischiomeral seta; E, first pereiopod, chela; F, same, tips of fingers, dactyl above; G, same, fixed finger, central cutting edge; $H$, third pereiopod; I, first pleopod, endopod; $\mathrm{J}$, second pleopod, appendix masculina and appendix interna. 
producing fossa. The fixed finger is similar. The single male second pereiopod is also similar but the merus bears only two distoventral teeth, instead of three.

Comparison of the Lizard Island specimen with the holotype of $P$. denticulatus, and with the specimens of $P$. denticulatus from Eniwetak Atoll, leaves little doubt as to its identity, despite the lack of second pereiopods, and represents a considerable extension to the known range of the species as well as an addition to the Australian fauna. Periclimenes denticulatus appears to be a naturally rare species, although two of its closest relatives, $P$. spiniferus de Man, occurring throughout most of the Indo-west Pacific region, and $P$. petitthouarsii (Audouin) in the western Indian Ocean, Red Sea, Persian Gulf region, are amongst the commonest coral reef shrimps. Periclimenes denticulatus shares with these two species, and also with $P$. sibogae Holthuis, the presence of a median tooth on the fourth thoracic sternite and a pair of very acute submedian teeth on the fifth, with long, slender first pereiopods with strongly subspatulate chelae, with pectinate lateral cutting edges to the fingers, elongate second pereiopods, similar or dissimilar, fingers with or without sound-producing fossae, and ambulatory pereiopods with simple dactyls.
Distribution. Type locality - Gatavake, Mangareva Atoll, Gambier Islands. Also known from Arno and Enewetak Atolls, Marshall Islands; Raroia Atoll, Tuamotu Islands; and from the northern South China sea. Not previously reported from Australian waters.

Periclimenes platycheles Holthuis, 1952

Fig. 15

\section{Restricted synonyny}

Periclimenes (Harpilius) platycheles Holthuis, 1952: 85-87, fig.33.--Miyake \& Fujino, 1968: 409-410, fig.3c-f.

Periclimenes platycheles.-Bruce, $1983: 196$.

Material examined. (i) 1 male, 1 ovig. female, stn Qld278, between Palfrey and South Islands, Lizard Island, $21 \mathrm{~m}$, trap, 29-30 Jan. 1989, coll. J.K. Lowry, S.J. Keable, AM P39304. (ii) 1 female, with hemiarthrinid bopyrid, stn Qld142, off Eagle Island, Lizard Island, $9 \mathrm{~m}$, trap, 13-14 Jan. 1989, coll. J.K. Lowry, AM P39292.

Remarks. The species has been previous reported

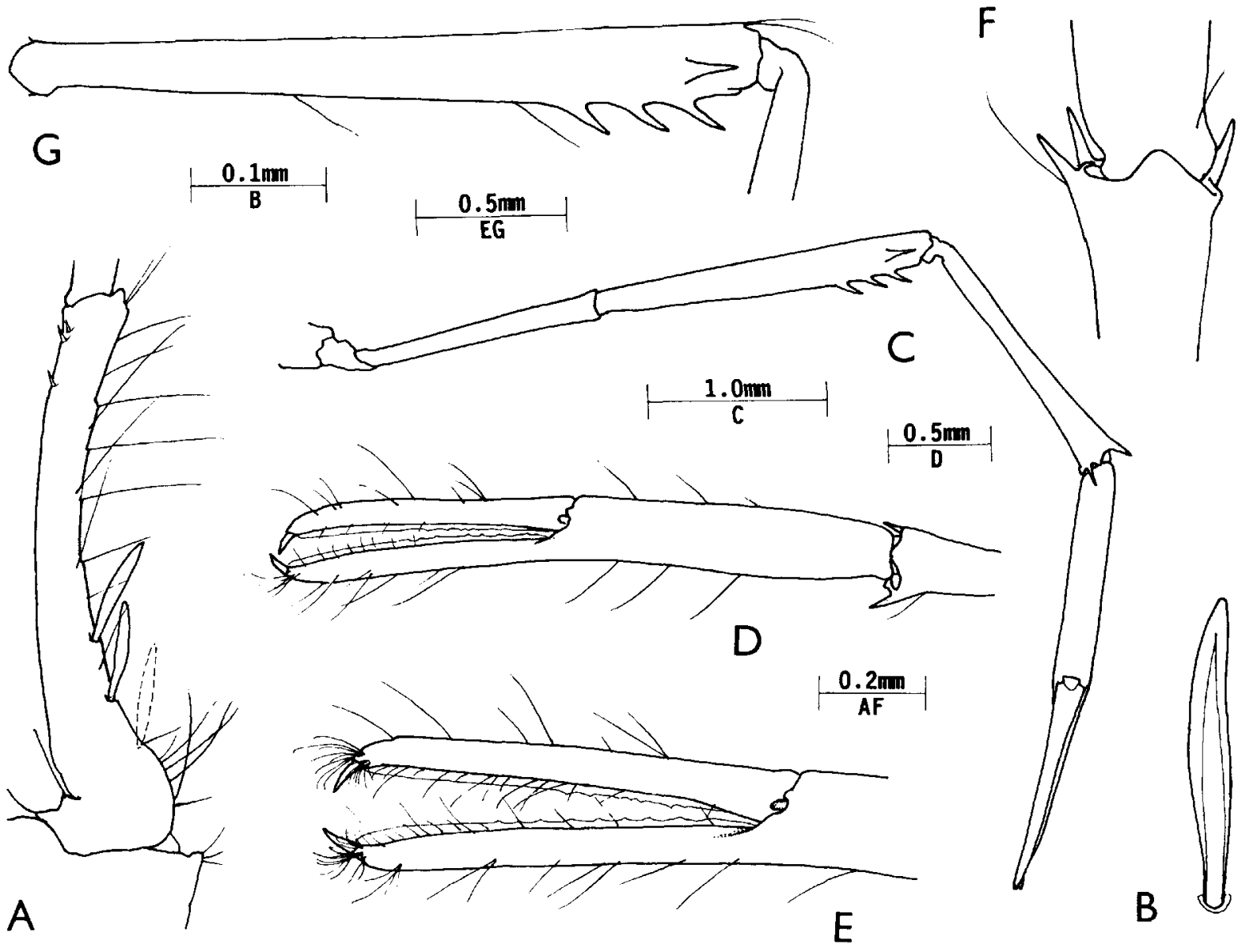

Fig.14. Periclimenes denticulatus Nobili, Enewetak Atoll, female. A, third maxilliped, ischiomeral-basal region of endopod; B, same, medial fusiform seta; C, second pereiopod; D, same, chela; E, same, fingers; F, same, carpopropodal joint; G, same, merus. 


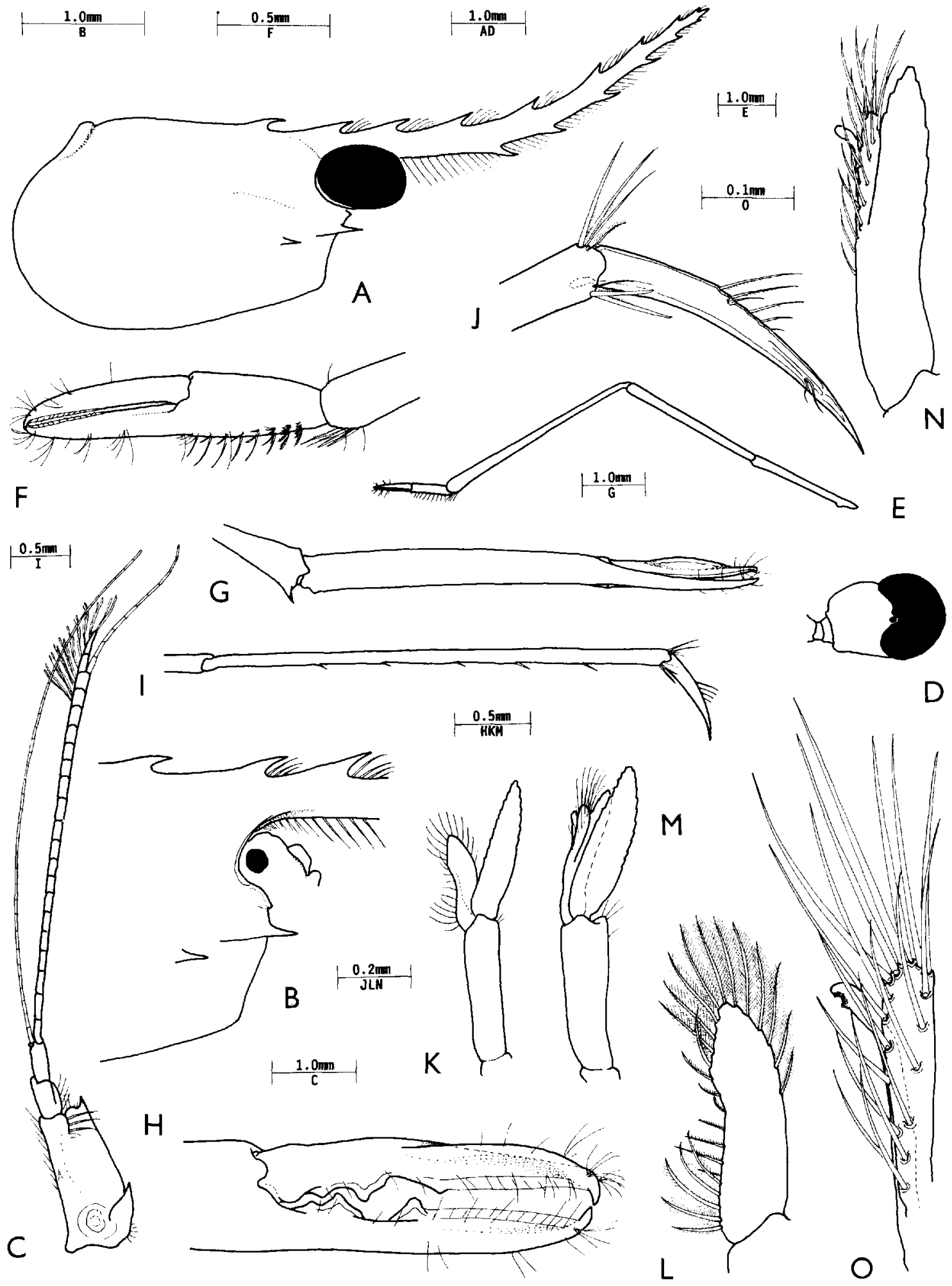

Fig.15. Periclimenes platycheles Holthuis, 1952, Lizard Island. A, carapace and rostrum; B, same, orbital region; $C$, antennule; $D$, eye; $E$, first pereiopod; $F$, same, chela; $G$, second pereiopod, chela; $H$, same, fingers; I, third pereiopod, propod and dactyl; J, same, distal propod and dactyl; K, first pleopod; L, same, endopod; $\mathrm{M}$, second pleopod; $\mathrm{N}$, same, endopod; $\mathrm{O}$, same, appendix masculina and appendix interna; A-F, K-O, male; $\mathbf{G}, \mathrm{H}$, female; I,J? 
from Lizard Island, from $14 \mathrm{~m}$, by Bruce (1983). The present specimens agree closely with the original description. The male specimen, CL $3.3 \mathrm{~mm}$, has the rostrum distinctly up-curved distally, with a dentition of $1+8 / 6$. Both female specimens, CLs $3.5,2.6 \mathrm{~mm}$, have a dentition of $1+8 / 5$. The type material had only $1+$ $6 / 4$ (ovig. female) and $1+6 / 6$. The rostrum is about 1.75 times the carapace length. The inferior orbital angle is slightly produced, with a small ventral inner flange, the dorsal border is convex. The antennal spine is at a much lower level than the inferior orbital angle, which it far exceeds, and is broad, with a distinct carina laterally. The antennular peduncle is as previously described, with an acute tooth ventrally at the middle of the medial margin of the proximal segment. The upper flagellum has the rami fused for the 19 proximal segments in the male specimen, with the shorter flagellum consisting of only two short segments, and the longer flagellum of ten very slender segments. The stout upper flagellum, which is 1.5 times the carapace length, contrasts strongly with the lower flagellum, which is slightly longer and very slender, with about 35 poorly demarcated segments. About nine groups of aesthetascs are present distally. The eye has a large globular cornea, the diameter equal to about one third of the carapace length, with a distinct dorsal accessory pigment spot. The ophthalmic somite is without a bec ocellaire. The fourth thoracic sternite is armed with a slender finger-like median process and the fifth bears a transverse posterior ridge, with a small median notch. The third sternite is broad and the third maxilliped bears a vestigial arthrobranch with three rudimentary lamellae. The first pereiopod appears more slender than in Holthuis' illustrations (fig.33c), with the carpus about 2.75 times the chela length and distinctly longer than the merus. The fingers are about 1.2 times the palm length, slender, with short hooked tips, the cutting edges are sharp over the distal halves of the finger lengths and entire. They do not closely resemble those of $P$. petitthouarsi and $P$. spiniferus, as reported by Holthuis. The chela in Holthuis' figure appears quite distinct from that of $P$. sibogae (fig.28c), which is also closely similar to that of $P$. petitthouarsi and $P$. spiniferus, with the fingers much broader, far longer than the palm and with pectinate cutting edges. The male specimen has both pereiopods in an early stage of regeneration, the associated female has only a single second pereiopod preserved. The palm of the chela is slender, suboval in section, about 6.5 times longer than wide, twice the length of the fingers. The dactyl is slender, with a strongly hooked tip, the distal half of the cutting edge sharp, entire, with the proximal half bearing a small distal tooth, separated by a deep notch from a large irregular central tooth, with a smaller tooth proximally; the distomedial aspect of the dactyl bears a distinct flange. The fixed finger is similar, without a flange, but the distal tooth is larger, opposing into the large dactylar diastema and separated from the central tooth by a broad deep notch. The carpus bears one welldeveloped acute distal spine, with a subacute lobe dorsomedially. The ambulatory pereiopods are slender, with the propod about 25 times longer than wide, with a pair of long distoventral spines, finely pectinate proximodorsally, with about five shorter single spines ventrally. The dactyl is about 0.21 of the propod length, slender, curved, about 8.5 times longer than the proximal width, with an obscurely demarcated unguis, about 0.5 of the corpus length. The penultimate fourth of the dorsal border of the corpus bears a longitudinal row of five setae, of decreasing size distally, with the proximal ventral margins finely setulose. The male first pleopod has the basipodite about 4.0 times longer than wide, with the endopod about 0.7 of the basipodite length, 3.75 longer than the proximal width, slightly expanded distally, without a medial accessory lobule, the proximal fourth of the medial margin with five long coarsely setulose setae, the central half with seven serrulate spiniform setae, the distal medial and lateral margins having 12 short plumose setae. The second pleopod has the basipodite about 3.2 times longer than its distal width, subequal to the first basipodite length. The endopod is about 0.9 of the basipodite length, 1.5 times the first endopod length, with the appendices about 0.5 of the median margin length. The corpus of the appendix masculina is about 5.0 times longer than its distal width, 0.35 of the endopod length, falling far short of the tip of the endopod, with a longitudinal row of seven ventral spines, a similar row of seven medial spines and a group of five longer distal spines, all simple, non-setulose. The appendix interna is slender, subequal to the appendix masculina, feebly cincinnulate.

Parasites. The specimen from stn Qld-142 had a lateral abdominal hemiarthrinid parasite, Metaphryxus intutus Bruce, (Isopoda, Bopyridae), an association that represents a new host record. The parasite was attached, in typical fashion, to the left side of the host's abdomen, raising a small lateral flange on the lateral aspect of the first segment.

Distribution. Type locality - Fau Island, Gebe Island, Indonesia, $31 \mathrm{~m}$. Also previously reported from Atiationin, Irian Jaya (paratype) $(57 \mathrm{~m})$; Palau, Caroline Islands, and Lizard Island, Queensland.

\section{Periclimenes agag Kemp, 1922}

Fig. 16

Restricted synonymy

Periclimenes (Ancylocaris) agag Kemp, 1922: 197-201, figs 47-50, pl.7 fig.9.-Gurney, 1938: 16.

Periclimenes (Harpilius) agag.-Ledoyer, 1984: 27-28.

Material examined. (i) 1 male, 1 female, stn Qld-136, Coconut Beach, Lizard Island, $17 \mathrm{~m}$, clean sand, trap, 11-12 Jan. 1989, coll. J.K. Lowry and S.J. Keable, AM P39288; (ii) 1 male, stn Qld-143, near Eagle Island, Lizard Island, $12 \mathrm{~m}$, rubble and sand, trap, 13-14 Jan. 1989, coll. J.K. Lowry and S.J. Keable, AM P39297; (iii) 11 specimens, stn Qld-202, southern end of Mrs 
Watson's Bay, Lizard Island, $1 \mathrm{~m}$, mangrove creek, trap, 23-24 Jan. 1989, coll. J.K. Lowry, S.J. Keable, AM P39297.
Remarks. The specimens correspond well with the description provided by Kemp (1922). The rostrum is slender, distinctly exceeds the carapace length and the

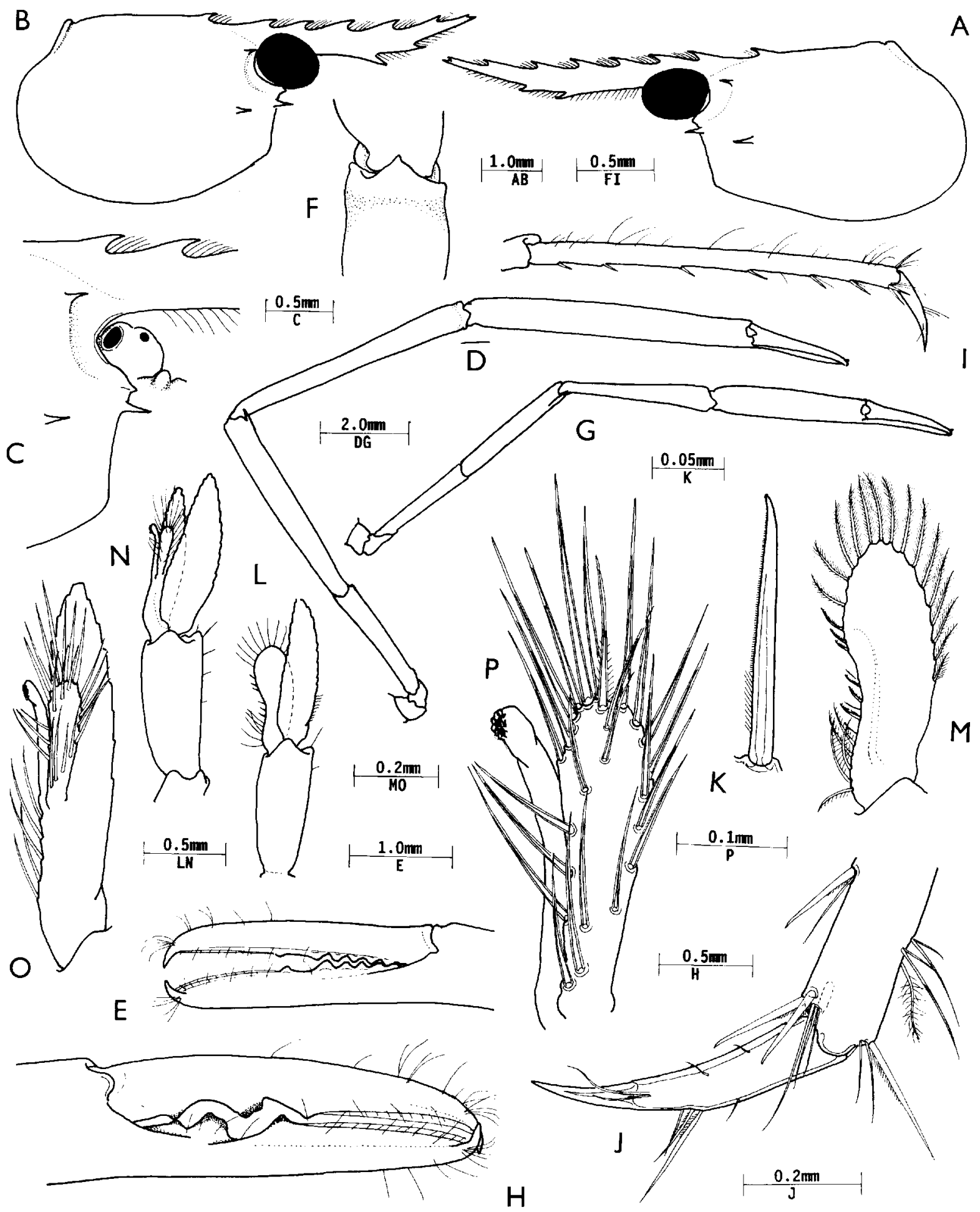

Fig.16. Periclimenes agag Kemp, 1922, Lizard Island. A,B, carapace and rostrum, lateral; C, same, orbital region; D, second pereiopod; E, same, fingers; F, same, carpopropodal joint, dorsal; G, second pereiopod; $\mathrm{H}$, same, fingers; I, third pereiopod, propod and dactyl; J, same, distal propod and dactyl; $\mathrm{K}$, same, distoventral propodal spine; L, first pleopod; M, same, endopod; N, second pleopod; O, same, endopod; P, same, appendix masculina and appendix interna. A,D,E,F,I-P, male; B,C,G,H, ovigerous female. 
tip of the scaphocerite, and is slightly longer in the male than in the female, with a dentition of $1+6-7 / 2-3$, except for a specimen from Qld-202, the largest male specimen, CL $3.4 \mathrm{~mm}$, which is unusual in having two epigastric spines situated close together, separated by a large gap from the rest of the dorsal rostral teeth. The supraorbital spines are well developed and a lateral orbital ridge is feebly indicated. The inferior orbital angle is slightly produced with a small ventral inner flange. The antennal spine is slender, marginal and exceeds the inferior orbital angle. In Kemp's illustration (fig.47), the antennal spine appears more robust and distinctly postmarginal, in contrast to the other species in his Periclimenes grandis group. The hepatic spine is at a slightly lower level, slightly posterior to the level of the supraorbital spine. The merus of the first pereiopods is about twice the length of the chela. The second pereiopods are very well developed, long and slender. In the male, the scaphocerite is exceeded by the distal third of the merus. The carpus has a small subacute tooth on the inner side and the ischium bears a small distoventral tubercle in large male specimens. In the male, the chela is about 1.5 times the carpus length and in females, about 1.6 times. Most of the 11 specimens from Qld-202 have all pereiopods detached and only few second pereiopods preserved. The male from Qld-143 has both preserved and the pair from Qld-136 only lacks one second pereiopod from the male. The fingers are about 0.36 of the palm length in the male, 0.55 in the female. In the male, a low, subacute tooth is present at about the middle of the cutting edge length, separated by a shallow gap from a proximal series of five low blunt teeth. The distal cutting edge is entire and the tip strongly hooked. In the single pereiopod of the female specimen the teeth are much more strongly developed and fewer in number, with more deeply developed interspaces. The third pereiopod is moderately slender, with the propod about 4.5 times the dactyl length, 14.5 times longer than wide, with a pair of long distoventral spines and six welldeveloped ventral spines, and the fifth pereiopod distinctly exceeds the scaphocerite. The dactylus is compressed, curved, simple, with a feebly demarcated unguis, 5.0 times longer than the proximal width, a longitudinal group of three slender setae at about 0.5 of the dorsal margin length, the two larger setae being finely setulose proximoventrally, the corpus with a pair of slender setae distolaterally and a few short ventral setae. The male first pleopod has the basicerite 2.5 times longer than wide, with the endopod about 0.8 of the basipodite length, 3.1 times longer than distal width, slightly expanded distally, medial margin concave, without accessory lobule, proximal fourth with four coarsely setulose setae, central half with about seven serrulate spines, distal and lateral margin with 15 short plumose setae. Second pleopod with basipodite 2.4 times longer than wide, 1.1 times first basipodite length; endopod 5.5 times longer than wide, subequal to basipodite length, with appendices at 2.4 of medial margin length, appendix masculina with corpus subcylindrical, slightly swollen distally, 3.4 times longer than distal width, reaching to point at 0.75 of endopod length, with ten ventromedial, four distoventral, eight ventrolateral and two to three distal spines, one feebly setulose proximally, others simple; appendix interna, slender, subequal to appendix masculina with few distal cincinnuli only.

Distribution. Type locality - Port Blair, Andaman Islands, $(7-15 \mathrm{~m})$. Also reported from the Red Sea and New Caledonia. Not previously reported from Australian waters.

\section{Periclimenes amboinensis (De Man, 1888)}

Figs 17,18

Restricted synonymy

Anchistia amboinensis De Man, 1888: 546, pl. 22a fig. 2. Periclimenes amboinensis.-Borradaile, 1898: 385.-Bruce, 1983a: 874-875, figs $1-3,7 \mathrm{e}$.

Periclimenes (Corniger) amboinensis.-Borradaile, 1917: 366. Periclimenes (Ancylocaris) amboinensis.-Kemp, 1922: 172. Periclimenes (Harpilius) amboinensis.-Holthuis, 1952: 10.

Material examined. 1 male, 1 juvenile, stn 26.1.0, Marx Reef, $15^{\circ} 12^{\prime} \mathrm{S} 145^{\circ} 37^{\prime} \mathrm{E}, 3.0^{\prime} \mathrm{m}, 21$ July 1988 , coll. K. Fabricius, NTM Cr.006835.

Host. Himerometra magnipinna A.H. Clark (Echinodermata, Crinoidea).

Remarks. The larger specimen is remarkable in that the cornea of the left eye is distinctly conoidally produced while that of the right eye is smoothly rounded. The conoidal corneal process is a character of major taxonomic importance, and its presence was at one time used as a basis for the distinction of the subgenus Corniger by Borradaile (1915). Loss or non-development of this process of both eyes would probably have resulted in the description of a new species.

The male specimen otherwise conforms closely to the data provided from Indonesian material by Bruce (1983a). The rostrum slightly exceeds the antennular peduncle and has six dorsal teeth and one small ventral tooth. The epistomal horns are well developed. The first four thoracic sternites are broad, all unarmed, the fifth narrow, and the following sternites relatively broad, also unarmed. The proximal segment of the antennular peduncle has a strong ventromedial tooth, the distoventral angle bears a single acute tooth only. The upper flagellum is biramous with the four proximal segments fused, the short ramus with only two free segments and the longer with ten slender segments; about nine groups of aesthetascs are present. The lower flagellum has about 14 slender segments. The scaphocerite distinctly exceeds the antennular peduncle, is 3.0 times longer than wide, with a small distolateral tooth far exceeded by the distal margin of the lamella. The mouthparts are as previously described, the broadened 
incisor processes of the mandibles having eight acute teeth on each side. The chela of the first pereiopod is slightly bowed, with slender fingers, about 0.8 of palm length, with entire sharp cutting edges distolaterally; the fixed finger is deeply channelled proximally and both fingers are very densely setose laterally. The chelae of

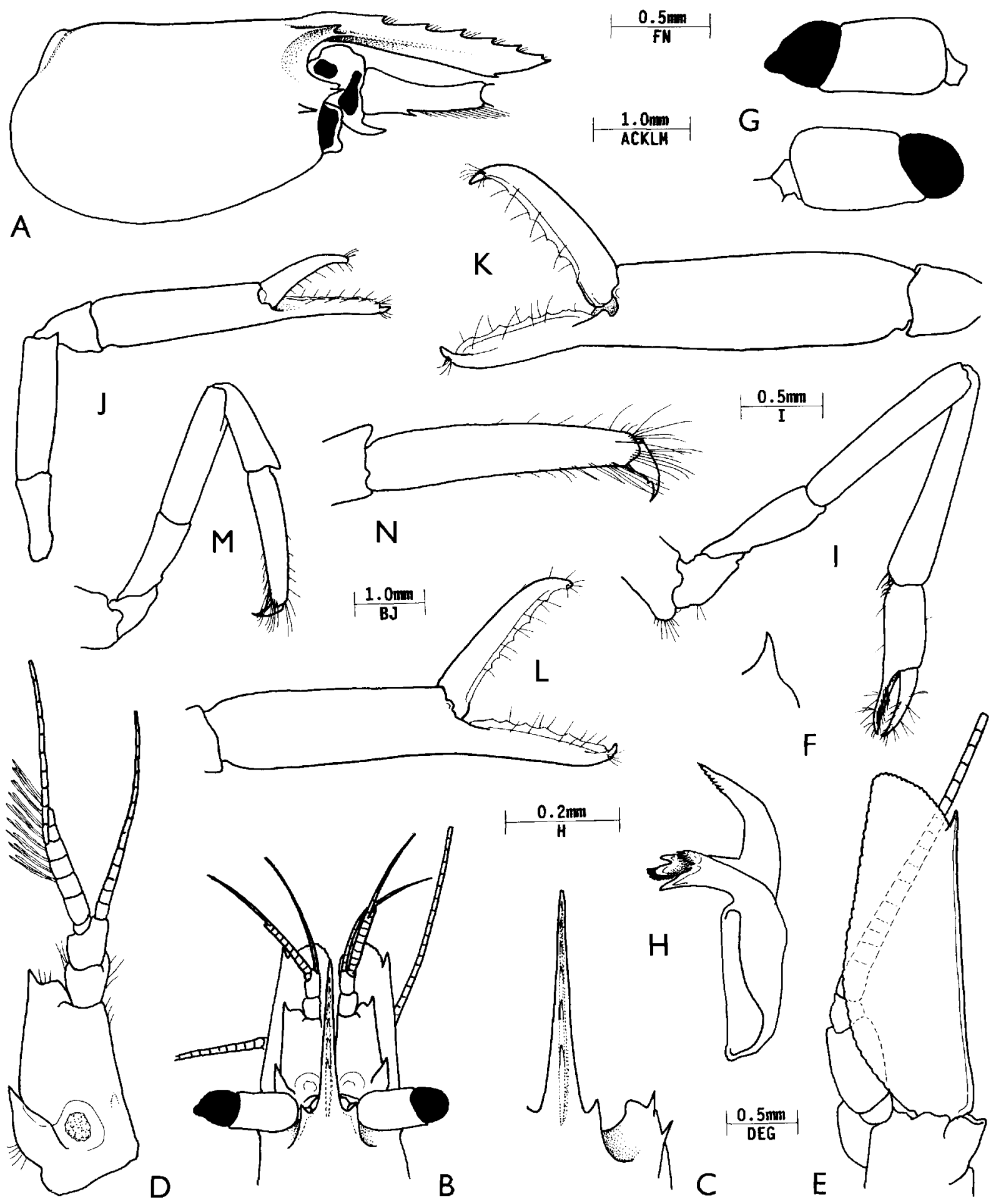

Fig.17. Periclimenes amboinensis (De Man), Marx Reef, male: A, carapace and rostrum, lateral right antennal peduncles removed, showing right epistomal horn; B, anterior carapace, rostrum, antennal peduncles, dorsal; $\mathrm{C}$, right orbital region, dorsal; D, antennule; E, antenna; F, right epistomal horn, dorsal; G, eyes, (upper, left; lower, right), dorsal; H, mandible; I, first pereiopod; J, second pereiopod, major; $\mathrm{K}$, same, chela; L, minor second pereiopod, chela; $\mathrm{M}$, third pereiopod; $\mathrm{N}$, same, propod and dactyl. 
the second pereiopods are slightly unequal, similar, the major chela about 1.2 times the carapace length, palm 3.2 times longer than wide. The merus has a strong acute distoventral angle. The ambulatory pereiopods are robust, with the distoventral angle of the merus unarmed. The propod is about 5.0 times longer than wide, slightly tapering distally, with a pair of short, slender distoventral spines and three small isolated ventral spines on the distal fourth, all largely obscured by groups of long, relatively stout simple setae. The dactyl is curved, about 0.2 of the propod length, with the unguis clearly demarcated, about 0.68 of the corpus length; corpus compressed with a small erect acute distoventral tooth, ventral border sinuous, with three long sensory setae distolaterally. The endopod of the first pleopod is 3.5 times longer than broad, distally rounded, without a median accessory lobule, the proximal medial border bearing five slender simple spines and the distolateral margin with four short plumose setae. The second pleopod has the appendix interna distinctly exceeding the appendix masculina. The corpus of the appendix masculina is about 0.28 times longer than distal width, with five spinulate ventral setae, of increasing length distally, and two long stout spinulate distal setae, the longer subequal to the corpus length. The caudal fan is normal, the telson with small dorsal spines at about 0.5 and 0.75 of its length. The lateral posterior spines are longer than the dorsal spines, and the submedian spines are finely setulose.

The juvenile specimen has a CL of $1.15 \mathrm{~mm}$, with the carapace and rostrum $2.45 \mathrm{~mm}$. The rostrum has three small acute dorsal teeth and a single small ventral tooth. The cornea is hemispherical, about 0.82 of the stalk length, 0.33 of the carapace length, quite without any conoidal process. The second pereiopods are subequal, with the chela subequal to the carapace length, fingers about 0.55 of palm length, palm 2.5 times longer than wide. The ambulatory dactyl is similar to that of the adult. The propod is also similar, with two slender distal spines and two small single ventral spines, but distinctly less setose, with only a few broad, rather spiniform setae.

Distribution. Type locality - Ambon, Indonesia.
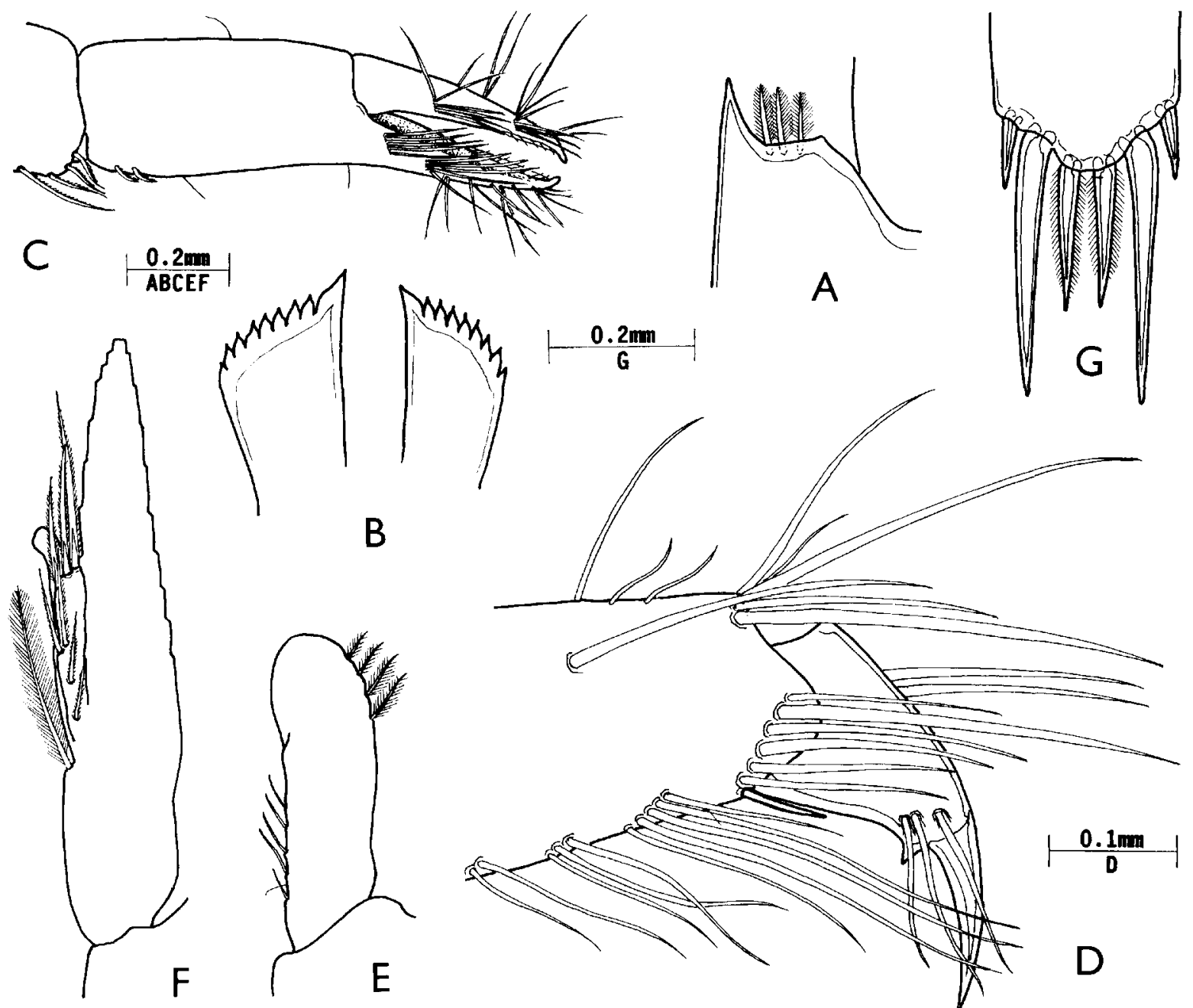

B
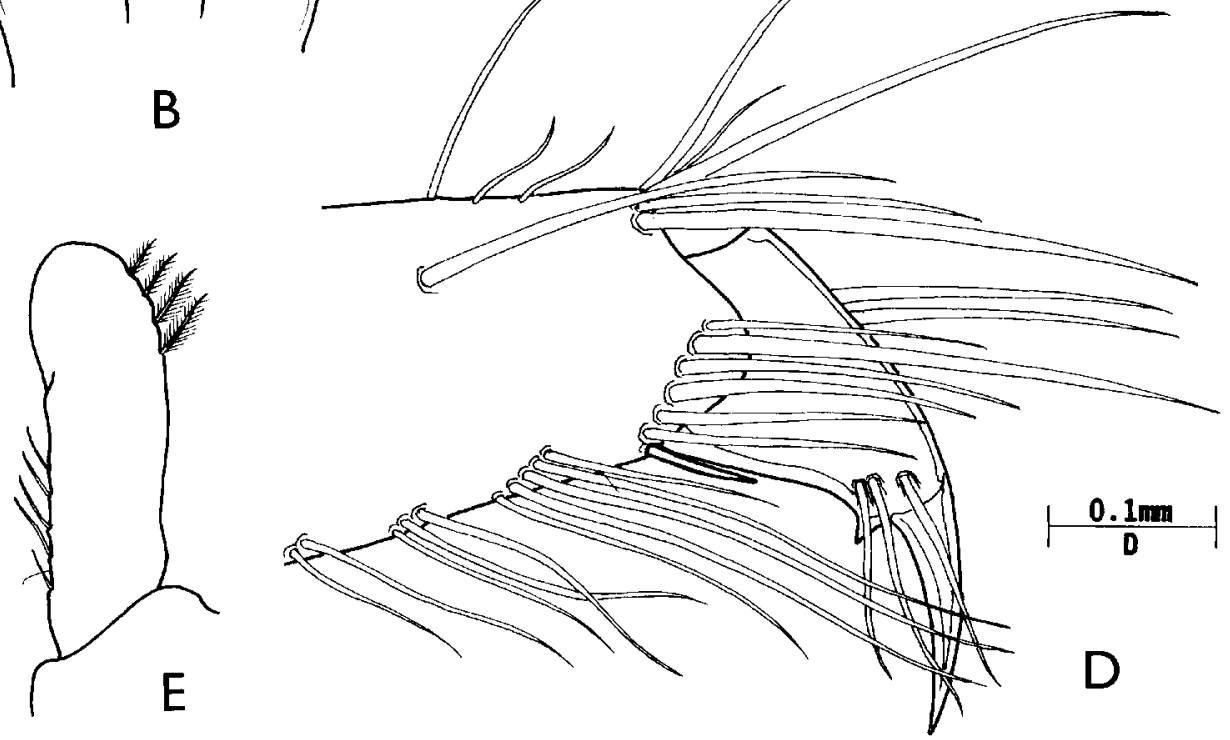

Fig.18. Periclimenes amboinensis (De Man), Marx Reef, male, A, proximal segment of antennular peduncle, distolateral angle; B, mandibles, incisor processes; C, first pereiopod, chela; D, third pereiopod, distal propod and dactyl, lateral, (many medial setae omitted); E, first pleopod, endopod; F, second pleopod, endopod. 
Also known from Marsegu Island, Ceram and Banda, Indonesia, the Great Barrier Reef, New Caledonia and the Marshall Islands.

\section{Periclimenes attenuatus Bruce, 1971}

Fig. 19

Restricted synonymy

Periclimenes attenuatus Bruce, 1971: 533-542, figs 1-5.Bruce, 1983: 206.-Bruce, 1983a: 879.

Material examined. 1 male, 1 ovig. female, 42/1/1, Rib Reef, $18^{\circ} 29^{\prime} \mathrm{S} 147^{\circ} 53^{\prime} \mathrm{E}, 10 \mathrm{~m}$, north reef front, 4 Nov. 1989 , coll. K. Fabricius, NTM Cr.006836.

Host. Comaster multifidus (J. Müller, 1841) (Echinodermata: Crinoidea).

Remarks. The female specimen has a carapace length of $2.8 \mathrm{~mm}$ and is the first ovigerous female reported. The type material was considered to be possibly immature, a finding that is confirmed by the present specimen, which is considerably more robust, with a much more strongly developed major second pereiopod. The major second pereiopod is lacking in the associated male. The present female differs from the holotype in having a rostral dentition of $4 / 0$, with a small preterminal tooth, instead of $3 / 0$. In both specimens the cornea is distinctly conoidally produced, whereas it was described as globular in the type specimens, although figured as very feebly produced. The chela of the female major second pereiopod has the palm subcylindrical, feebly compressed, slightly swollen proximally, about 3.2 times longer than proximal width, with the fingers about 0.37 of palm length, the dactyl about 3.75 times longer than proximal depth, rather swollen proximally, with feeble lateral flange, the cutting edge bears a much larger, broad, blunt tooth proximally, fitting into a large fossa on the fixed finger, with a ventrolateral flange laterally; the distal cutting edge is sinuous, proximally entire, distally finely serrate, with a large curved blunt tip; the fixed finger has two large teeth proximally, the most proximal low, irregularly blunt, the distal tooth, slender, strongly produced, blunt, fitting into a deep fossa on the dactylus, the distal cutting edge similar to the dactylus. The ova are numerous and small, about $0.45 \mathrm{~mm}$ in length.

Periclimenes attenuatus has not been previously recorded in association with Comaster multifidus.

Distribution. Type locality - Burukuk Island, Duke of York Islands. Also known from Lizard Island, Queensland, and from Sawai, Seleman Bay, Seram, Indonesia.

\section{Periclimenes laccadivensis (Alcock \& \\ Anderson, 1894)}

Fig. 20

Restricted synonymy

Palaemonella laccadivensis Alcock \& Anderson, 1894: 157.Rathbun, 1906: 925, pl.20 fig.2.

Palaemon (Brachycarpus) laccadivensis,-Alcock, 1901: 138 (partim).

Periclimenes (Periclimenes) laccadivensis.-Kemp, 1922: 153154, figs 19-20.-Holthuis, 1952: 9.

Periclimenes laccadivensis.-Bruce, 1979: 225.

Material examined. I female, stn Slope 46, off Cape Freycinet, Tasmania, $40^{\circ} 20^{\prime} \mathrm{S} 148^{\circ} 37.70^{\prime} \mathrm{E}, 720 \mathrm{~m}$, coarse shelly sand, R.V. Franklin, WHOl epibenthic sled, 27 July 1986, coll. M.F. Gomon et al., NMV J.15873.

Description. The single example is fairly complete, but lacks the major second pereiopod and some of the ambulatory pereiopods. The carapace (CL $4.2-\mathrm{mm}$ ) is slightly distorted, but the rostrum is complete, about 0.9 of the carapace length, slightly upcurved, distally slender and slightly exceeding the antennular peduncle but not the scaphocerite, with eight acute dorsal teeth, the first tooth postorbital in position, and with two similar ventral teeth at about 0.5 of the rostral length. Compared with Kemp's illustrations (fig.19), the hepatic spine appears distinctly longer and more robust. The epigastric spine is also present and distinct. The inferior orbital angle is moderately produced, blunt, with the antennal spine marginal, at a slightly lower level, well above the level of the hepatic spine. The eye has a welldeveloped globular cornea, well pigmented, without a dorsal accessory pigment spot. The stalk is about as wide as long dorsally, moderately compressed. The first pereiopod is slender, with the carpus about 1.5 times the chela length. The chela has slender, straight, simple fingers, slightly shorter than the palm length. Only the right second (minor) pereiopod is preserved. The carpus and merus are unarmed, the chela has the palm smooth, about 5.0 times longer than wide, 0.6 of the carapace length, with the fingers about 0.6 of the palm length, very feebly armed with minute teeth proximally. The ambulatory pereiopods are normal, one third and both fourth pereiopods are lacking. The third pereiopod has the dactyl about 0.18 of the propod length, about 3.8 times longer than deep, with a distinct unguis, about 3.8 times longer than wide, 0.45 of the corpus length; the corpus bears a slender acute distoventral tooth, about 0.25 of the unguis length. The propod is about 11.7 times longer than wide, with several groups of long setae distoventrally, but without any spines. The fifth pereiopod propod and dactyl are similar, but the propod has a single distoventral spine and a single ventral spine at about 0.70 of the propod length, the long setae are also more numerous, especially distolaterally. The thoracic sternites are moderately broad and unarmed, the fourth lacks a finger-like median process. The telson is 


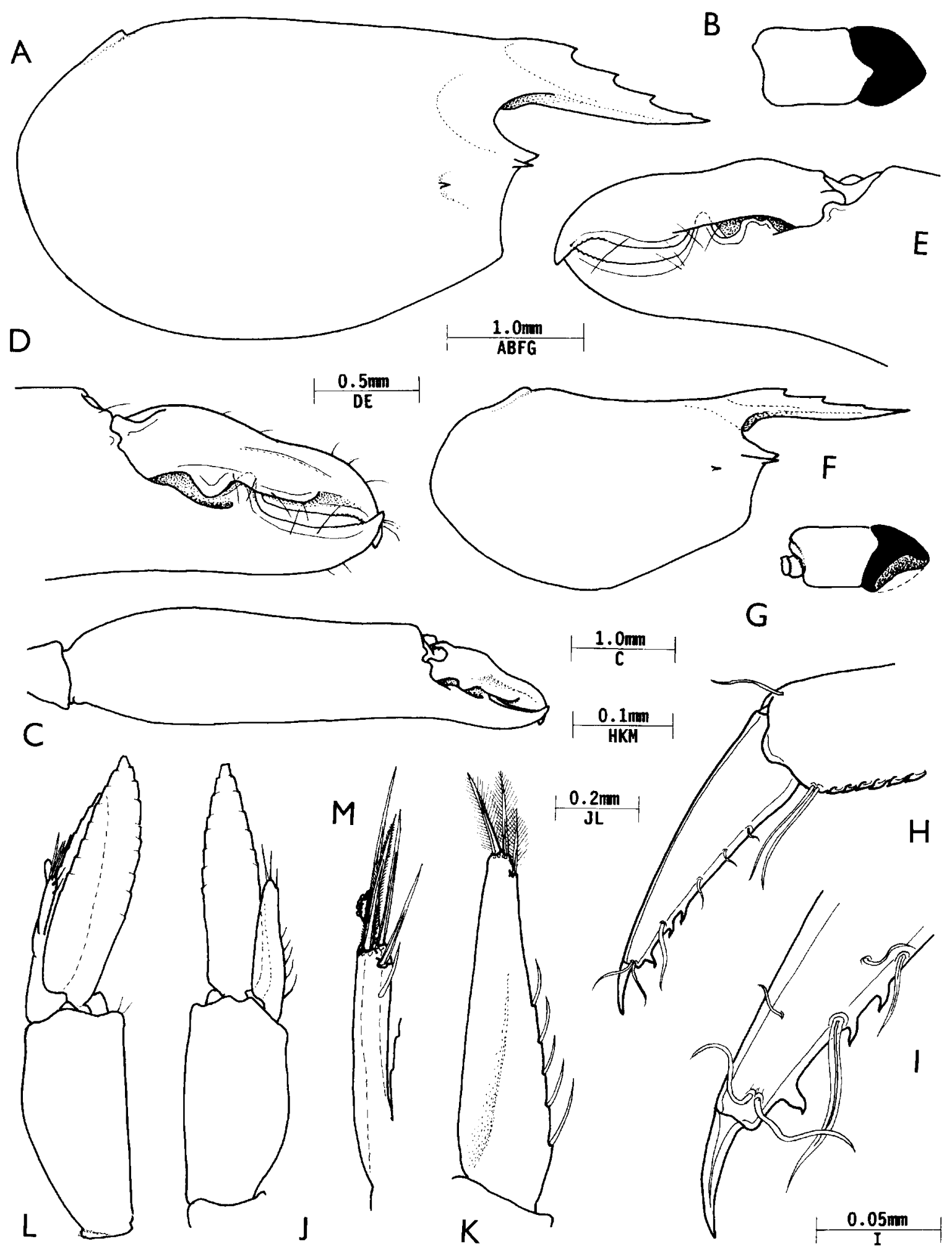

Fig.19. Periclimenes attenuatus Bruce, Rib Reef, Queensland. A, carapace and rostrum, lateral; B, eye; C, major second perciopod chela; D, same, fingers, lateral; E, same, medial; F, carapace and rostrum, lateral; G, eye; H, third pereiopod, dactyl and distal propod; I, same, distal dactyl; J, first pleopod; K, same, endopod; $\mathrm{L}$, second pleopod; M, same, appendix masculina and appendix interna. A-E, ovigerous female; F-M, ovigerous male. 
about 1.1 times the length of the sixth abdominal segment, 4.15 times longer than broad, with dorsal spines well developed, slightly irregularly placed, about 0.45 and 0.72 of the telson length, sub-erect, larger than lateral posterior spines; posterior margin triangular, without acute median point, lateral spines subventral, intermediate spines about 9.0 times longer than wide, 0.2 of the telson length, submedian spines about 0.4 of intermediate spine length, robust, about 6.5 longer than wide, bilaterally setulose, with a single median spine exactly similar to the submedian spines. The uropods are normal, with the lateral margin of the exopod with a small acute distal tooth, with a larger mobile spine medially.

The present specimen of $P$. laccadivensis differs only slightly from the data provided by Kemp (1922). The rostrum is slightly longer, and has only one instead of two postrostral teeth. The antennal spine appears slightly less robust and the hepatic spine better developed. The telson is unusual in having seven posterior marginal spines, but minor abnormalities of spinulation are comparatively common in these spines. These abnormalities are usually conspicuously asymmetrical and the appearance of perfect symmetry, as in the present specimen, is most unusual. The present record is also the first report of $P$. laccadivensis from the southern hemisphere and represents a considerable extension of the known range of this species. It also indicates the occurrence of this species outside the boundaries generally accepted to the shallow water components of the Indo-west Pacific fauna. Despite the great extension in range and the minor morphological
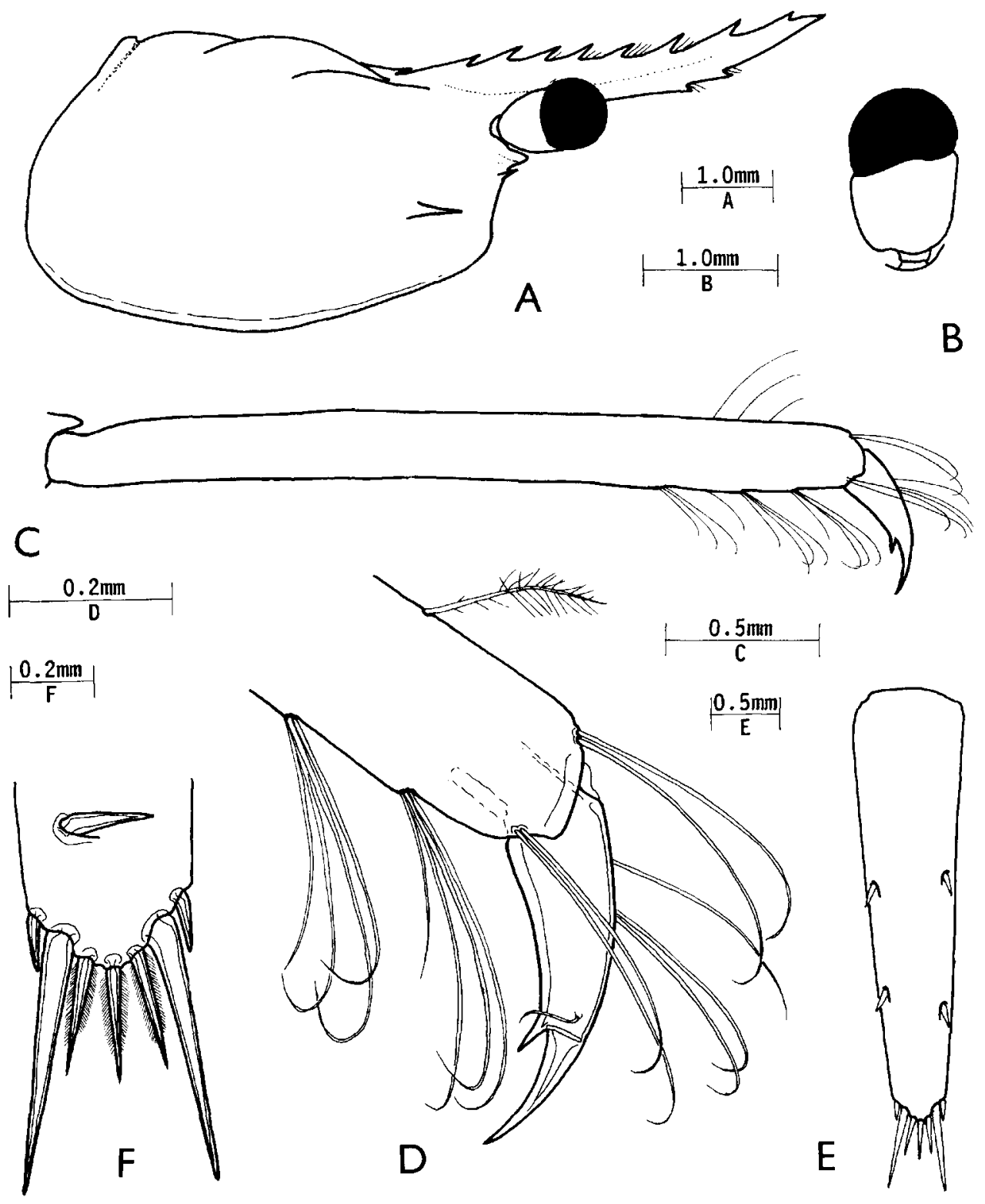

Fig.20. Periclimenes laccadivensis (Alcock \& Anderson), Tasman Sea, female. A, carapace and rostrum, lateral; B, eye, dorsal; C, third pereiopod, propod and dactyl; D, same, dactyl and distal propod; E, telson; $F$, same, posterior spines; dorsal spine, inset. 
differences, there is no adequate reason not to include this specimen under the name given.

Distribution. Type localities - Laccadive Sea, $10^{\circ} 47^{\prime} 45^{\prime \prime} \mathrm{N} 72^{\circ} 40^{\prime} 20^{\prime \prime} \mathrm{E}, 1285 \mathrm{~m} ; 7^{\circ} 17^{\prime} 30^{\prime \prime} \mathrm{N} 76^{\circ} 54^{\prime} 30^{\prime \prime} \mathrm{E}$, $786 \mathrm{~m}$. Also reported from the South China Sea, $19^{\circ} 02^{\prime} \mathrm{N}$ $112^{\circ} 39^{\prime} \mathrm{E}, 274-289 \mathrm{~m}$, and from Hawaii, off Kauai Island, $700-900 \mathrm{~m}$. Not previously recorded from Australian waters.

\section{"Periclimenes consobrinus" Balss, 1915}

Fig. 21

non Harpilius consobrinus De Man, 1902: 836-840, pl.26 fig. 54 .

Periclimenes consobrinus.-Balss, 1915: 27.

Material examined. NHMV unregistered - (i) 1 female, Yenbo; (ii) 1 male, Dahab; (iii) 1 female, Tor; (iv) 6 specimens, Ras Abu Somer.

Hosts. Not known, presumably Acropora spp.

Remarks. The examination of these specimens reported upon by Balss (1915) and collected by the 'Pola' Expedition to the Red Sea, have failed to confirm the presence of Periclimenes consobrinus De Man in the Red Sea. The distinction of $P$. consobrinus from $P$. lutescens (Dana), treated as synonymous by Kemp (1922) and Holthuis (1952), was demonstrated by Bruce (1972) and confirmed, with further detail, by Holthuis (1981). Re-examination of Balss' specimens has recently shown that some of the specimens he reported as $P$. consobrinus are actually $P$. lutescens, first reported from the Red Sea by Nobili (1901) and then Tattersall (1921), as Harpilius lutescens and $H$. depressus respectively, but also include some other pontoniine shrimps. The results of this re-examination are summarised below and some further details included.

Specimen (i): Philarius gerlachei (Nobili, 1905), male, CL $4.2 \mathrm{~mm}$. The single specimen lacks both second pereiopods, has a rostral dentition of $4 / 1$, and has a broad blunt triangular median process on the fourth thoracic sternite. The propods of the ambulatory propods are stout, devoid of spines, with transverse rows of numerous simple setae distally. The dactyl is comparatively feeble, compressed, strongly curved, with a distinctly demarcated unguis, 3.0 times longer than the proximal width, 0.4 of the corpus length, about 2.0 times longer than the proximal width, which is only about 0.4 of the width of the distal end of the propod. The ventral margin of the corpus is concave, sharp and entire, without a distal accessory tooth. The dactyl is highly mobile, flexing about $90^{\circ}$, both dorsally and ventrally.

Specimen (ii): Periclimenes lutescens (Dana, 1852), male, CL $4.7 \mathrm{~mm}$. The specimen has a rostral dentition of $7 / 2$, with the first tooth just posterior the posterior margin of the orbital notch, the rostrum distinctly exceeding the antennular peduncle, by the portion beyond the sixth dorsal tooth, generally similar to the figure provided by Kemp (1922), but the antennal spine is distinctly less robust. The fourth thoracic sternite has a short finger-like median process on a feeble transverse ridge. The second pereiopod chela is about 2.3 times the carapace length, with the palm subcylindrical, slightly swollen proximally, about 3.0 times longer than the proximal depth, fingers slender, about 0.75 of palm length, dactyl 5.4 times longer than proximal depth, with strong blunt curved tip, proximal cutting edge with five low similar teeth, distal cutting edge entire, sharp; carpus about 0.4 of palm length, 2.0 times longer than distal width, slightly expanded distally with blunt lobes; merus with distoventral angle acute, distomedial angle bluntly produced; ischium, basis and coxa normal. The second maxilliped endopod has the narrow elongate dactylar segment forming a continuous straight medial margin with the inner edge of the propodal segment. The ambulatory pereiopods are stout, with the propod robust, compressed and without spines, with numerous long simple setae, arranged in four main transverse rows distolaterally. These largely obscure the dactyl, which is relatively feebly developed, its length about subequal to the distal width of the propod, its basal width about 0.45 of the distal propod width, strongly curved, compressed, with slender distinctly demarcated unguis, 3.75 times longer than proximal width 0.4 of corpus length, corpus about 1.8 times longer than proximal width, ventral margin sharp, feebly concave, unarmed. The endopod of the first pleopod is about 4.5 times longer than the proximal width, with the distal half slightly expanded medially, with ten short plumose setae along the proximal half of the medial margin, becoming more spinulose distally; the distal half of the medial margin bears five similar setae proximally, changing to few feebly plumose setae distally; the lateral margin bears 12 short plumose setae. The endopod of the second pleopod has appendices at about 0.4 of the medial margin length with the appendix masculina far exceeding the appendix interna, with the corpus subcylindrical, reaching to about 0.66 of the endopod length, with six short simple ventromedial spines, seven similar ventrolateral spines, and five longer simple distal spines. The appendix interna reaches to about 0.6 of the appendix masculina length and has few distal cincinnuli.

Specimen (iii): Periclimenes lutescens (Dana, 1852), female, CL $4.5 \mathrm{~mm}$, with a rostral dentition of $7 / 2$.

Specimens (iv): (a) Periclimenes lutescens (Dana, 1852), 2 ovig. females, $C L 5.8,6.7 \mathrm{~mm}$. The larger specimen has a rostral dentition of $8 / 2$, the smaller, 5/ 2 , but with the distal portion missing. (b) Philarius imperialis (Kubo, 1940), 1 male?, CL $4.8 \mathrm{~mm}$, with a rostral dentition of $9 / 1$, with the first tooth situated on the carapace in an epigastric position and separated by a wider interval from the rest of the teeth; the carpus of the second pereiopod has two acute dorsal teeth. (The specimen appears to be provided with two left second pereiopods). Periclimenes imperialis has been previously reported from the Red Sea, from Elat, by 


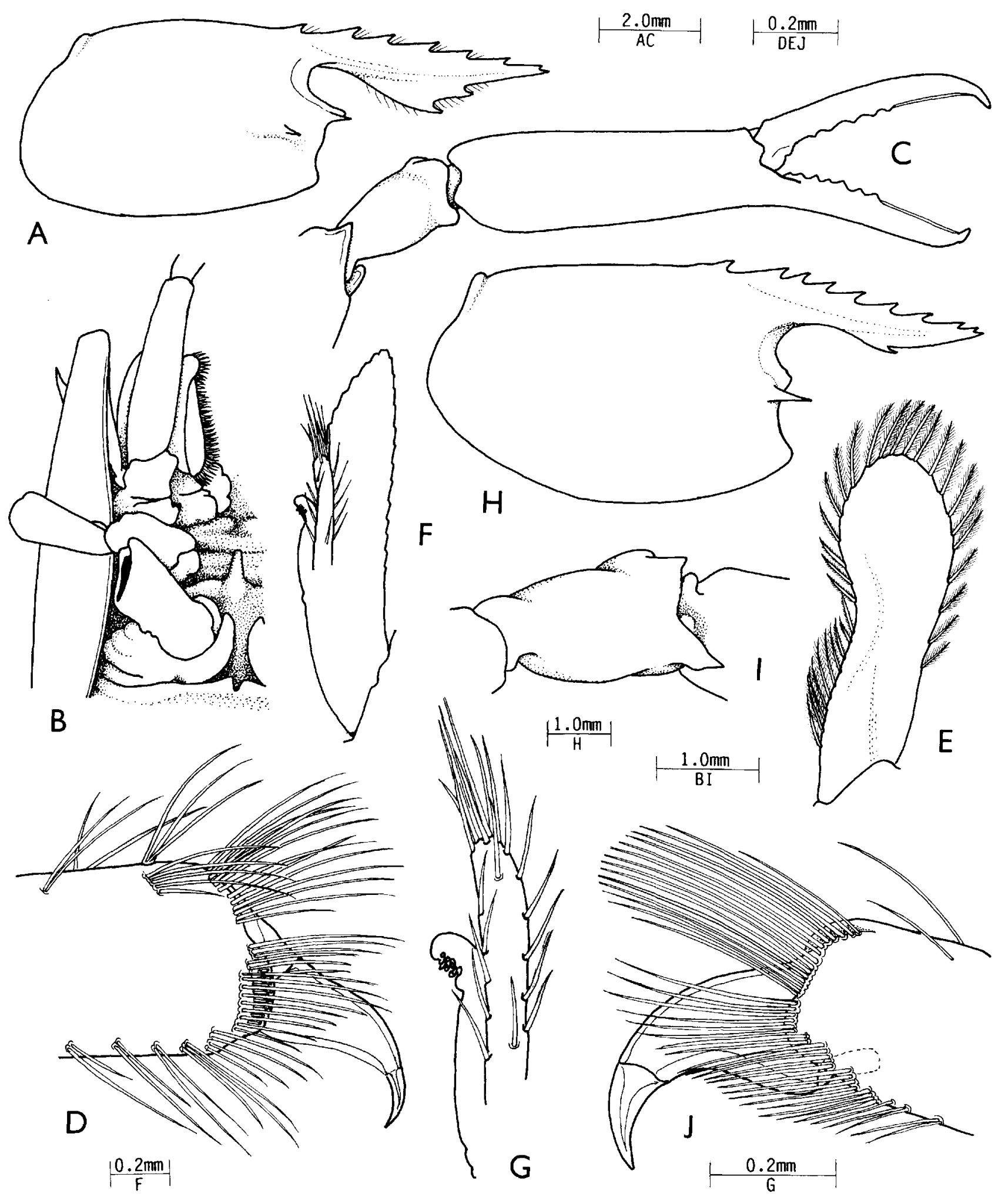

Fig.21. Periclimenes lutescens (Dana), Dahab, male. A, carapace and rostrum, lateral; B, anterior thoracic region, ventral; C, major second pereiopod, chela, lateral; D, third pereiopod (?), distal propod and dactyl; E, first pleopod, endopod; F, second pleopod, endopod; G, same, appendix masculina and appendix interna; Philarius imperialis Kubo, Ras Abu Somer, male?; H, anterior carapace and rostrum, lateral; I, second pereiopod, carpus, dorsal; Philarius gerlachei (Nobili), Yenbo, female; J, third pereiopod (?), distal propod and dactyl. 
Holthuis (1958). (c) Harpiliopsis depressa (Stimpson, 1860), 2 ovig. females, CLs $3.7,4.4 \mathrm{~mm}$, the larger with a rostral dentition of $6 / 4$, the smaller with $6 / 5$. Both specimens lack second pereiopods. The hepatic spine is situated at a much lower level than the antennal spine and so the specimens cannot belong to $H$. beaupresii (Audouin) and, as both specimens have a distinctly robust, stout body form, they are considered to belong to $H$. depressa rather than the slender $H$. spinigera (Ortmann), which has not yet been recorded from the Red Sea. Harpiliopsis depressa has been previously recorded from the Red Sea, first by Balss (1915). (d) Coralliocaris superba (Dana, 1852), 1 male, with a rostral dentition of $5 / 2$. The specimen lacks both second pereiopods, but is identified as $C$. superba rather than $C$. graminea (Dana), both of which are known from the Red Sea, on account of the cndopod of the third maxilliped having broadened segments.

Balss' material consists entirely of species now known to be associates of Acropora corals. Periclimenes consobrinus is an associate of pocilloporid corals, and examination of these hosts may reveal its presence in the Red Sea. Periclimenes consobrinus is known from Kenya, Tanganyika, Comoro Islands, La Réunion, Philippines, the Gulf of Thailand and the Great Barrier Reef.

\section{Periclimenes pholeter Holthuis, 1973}

Figs 22-23

Restricted synonymy

Periclimenes pholeter Holthuis, 1973: 30-35, figs 10-11.-Wear \& Holthuis, 1977: 139.

Material examined. (i) 100 specimens (5 ovig. females) R.V 'Meteor', Cruise 5, stn 184, 19'27.6' N 38'43.3'S, 1825 m, traps, 26 Feb. 1987, coll. (ii) 1 male, 2 female, Naweni Point, Vanua Levu, Fiji, $16^{\circ} 48^{\prime} 15^{\prime \prime S} 179^{\circ} 34^{\prime} 30^{\prime \prime}$ E, anchialine pool near mangrove swamp, 19 July 1983, coll. S. Choy, RMNH, unnumbered.

Remarks. The Red Sea specimens agree, with one exception of one point noted below, with the description and figures provided of the type material.

In the original description the inferior orbital angle is illustrated as a slender, blunt, up-turned process, whereas in the present material this feature is represented by a broad subacute shelf-like projection. A specimen of $P$. pholeter from Aldabra, kindly provided by Prof. L.B. Holthuis, has the inferior orbital angle precisely as in the present specimens, and Dr C.H.J.M. Fransen has also confirmed that it is similar in the type material.

Also, in the type material, the rostral dentition varies from 1+9-10/2-4. In the present material eight specimens lack an epigastric tooth, so that the rostral dentition is $0-1+7-10 / 0-3, \quad(82 \%$ with $1+9-10 / 1-2)$. The rostrum generally extends anteriorly to or beyond the end of the antennular peduncle. The dorsal carina is distinctly elevated and the ventral carina feebly developed. The proximal part of the ventral margin bears a vestigial double row of setae in some specimens, the distal portion being glabrous. A small tubercle is generally distinct, posterior to the epigastric tooth. The antennal spine is acute, marginal, slightly upwardly directed, distinctly larger than the hepatic spine. The corneal diameter appears similar in the present specimens and the type material, about 0.07 of the carapace length, with welldeveloped pigmentation and lacking a distinct accessory pigment spot. Out of 42 adult specimens sexed, only one proved to be male, which had the cornea of the right eye markedly reduced in size, that of the left appearing normal. The ophthalmic somite is without a bec ocellaire. The ventral medial margin of the proximal segment of the antennular peduncle bears a small acute tooth at about half its length. The scaphocerite is broadly rounded distally, feeble angled in the type specimen illustrated, with the lateral margin markedly thickened. The fourth thoracic sternite lacks a fingerlike median process but bears a low transverse carina with a pair of blunt submedian teeth separated by a $\mathrm{U}$ shaped notch. A similar carina is also present on the posterior fifth thoracic sternite. The third sternite is unarmed but the second bears a broad unarmed transverse ridge. The chelae of the second pereiopod are essentially as in the type specimens but in some specimens the palm is about 0.6 instead of 0.75 of the length of the chela and also possesses a pair of minute teeth proximally on the dactyls, with a single similar opposing tooth on the fixed finger. The dactyls of the ambulatory pereiopods are moderately compressed, with the unguis only feebly demarcated, about 0.4 of the corpus length, on the third pereiopod. The corpus is about 3.0 times longer than its proximal width, with a slender acute distal accessory tooth ventrally, less than half the length of the unguis. The distoventral spines of the propod are finely serrated along the dorsal margins. The dactyl of the fifth pereiopod is similar, but with a slightly reduced unguis. The distoventral propod is without distoventral spines but bears numerous serrulate spiniform cleaning setae. The endopod of the first pleopod, in the only male, shows a feeble indication of a small medial lobule, with the proximal half of the medial margin bearing seven plumose setae proximally and six small simple adpressed spinules distally; the distolateral margin hears 15 sparsely setulose setae. The appendix masculina of the male second pleopod is slightly longer than the appendix interna, with six long slender spines distally, some about 0.5 of the corpus length, with five ventrolateral distal spines and one ventromedial, some being minutely setulose. The telson is generally as in the type specimen but the submedian spines are less than the posterior marginal width of the telson, 1.75 times the submedian spine length. The submedian spines are finely setulose along the inner margin.

The minor details noted above leave no alternative to the conclusion that the Red Sea specimens from 1825 $\mathrm{m}$ are conspecific with the specimens from shallow 
water. Even the corneal diameter does not appear to have undergone any significant reduction in size in the deep-sea specimens (0.7: ca. 0.08 of the carapace length) and is deeply pigmented. The original material, 16 specimens, was described from an anchialine fissure on the Sinai Peninsula, the Ras Muhammed Crack, and

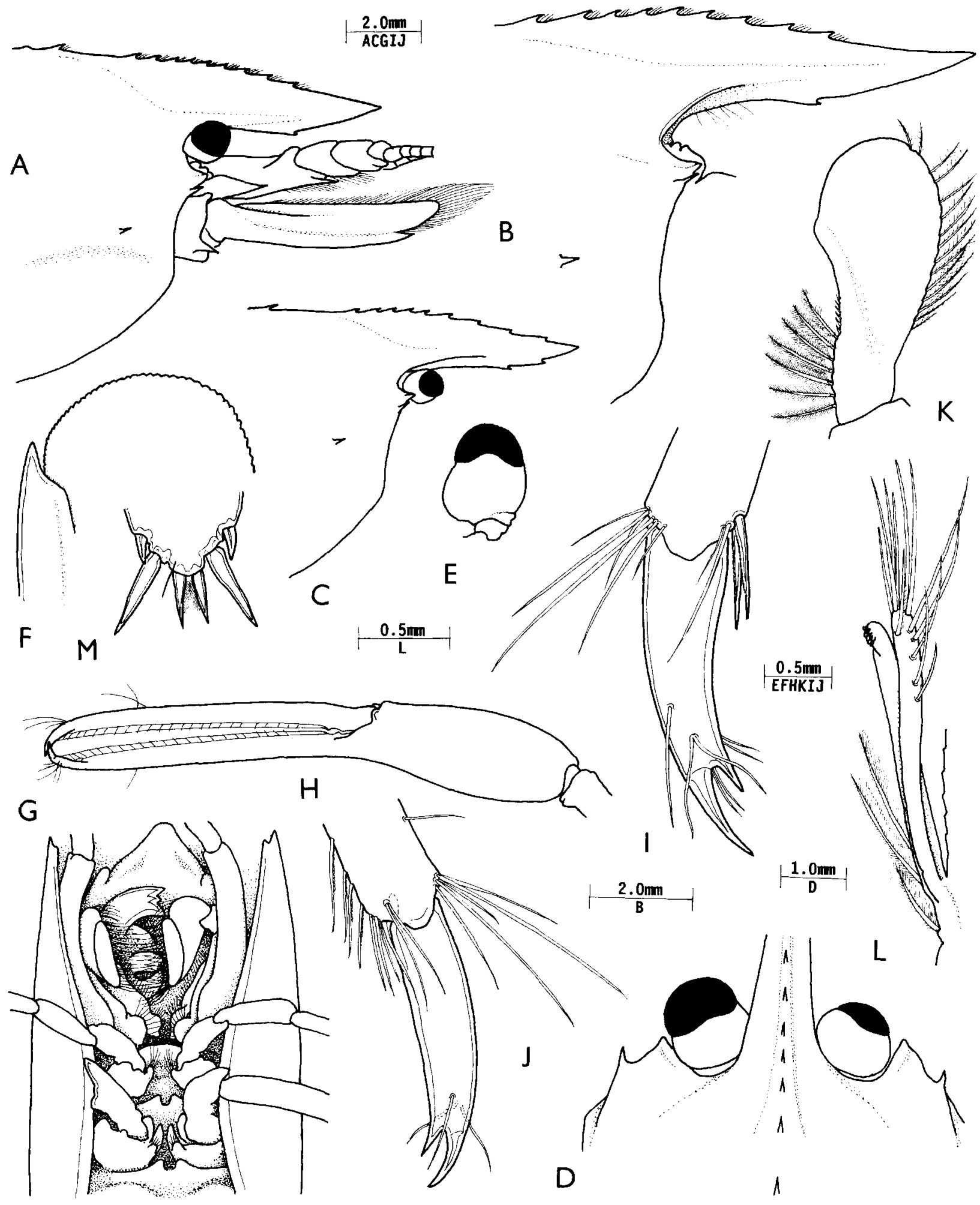

Fig.22. Periclimenes pholeter Holthuis, Red Sea. A, anterior carapace, rostrum, antennal peduncles; B,C, anterior carapace and rostrum; D, frontal region, dorsal; E, eye, dorsal; F, scaphocerite, distal end; G, anterior thoracic region; H, second pereiopod, chela; I, third pereiopod, dactyl and distal propod; J, fifth pereiopod, same; K, first pleopod, endopod; L, second pleopod, appendix masculina and appendix interna; $M$, posterior telson spines. A,B,E,F,G,H,I,J,M, female; C,D,K,L, male. 
$P$. pholeter has also since been reported from anchialine pools on Aldabra, Seychelle Islands. The occupants of both the anchialine and deep-sea habitats are often held to be relict survivors from shallower waters. Hart, Manning \& Iliffe (1985) mention several examples of crustacea occurring in shallow water marine caves, whose nearest relatives live at considerable depths. In no case reported does a single species occur in both zones. Periclimenes pholeter appears to be the first example of a decapod that has colonised and survived in both these habitats. The occurrence of $P$. pholeter at a depth of $1825 \mathrm{~m}$ may be partially explained by the hydrological conditions at this depth in the Red Sea. The water temperature at depths of $200 \mathrm{~m}$ or more is constant, between $21.5^{\circ} \mathrm{C}$ and $22^{\circ} \mathrm{C}$ (Türkay, 1986) and is therefore not as far removed from the anchialine habitat temperatures, $25.5^{\circ} \mathrm{C}$ (Holthius, 1973) as might otherwise have been expected. The presence of $P$. pholeter at $1825 \mathrm{~m}$ far exceeds the previously known maximal depth record for a palaemonid shrimp, held by $P$. laccadivensis (Alcock \& Anderson) from $1285 \mathrm{~m}$ in the Laccadive Sea.

The occurrence of such large numbers in traps clearly indicates that substantial populations are involved. Few traps set in deep water have provided specimens of palaemonid shrimps and those that have been recorded have only been in small numbers of specimens (Periclimenes sp., King, 1984; Bruce, 1990a) (1 spm); Periclimenes parvispinatus Bruce, 1990b (1 spm); Periciimenes poupini Bruce, 1990a (6 spms). It is interesting to note that $P$. pholeter has biunguiculate ambulatory dactyls, usually an indication of involvement
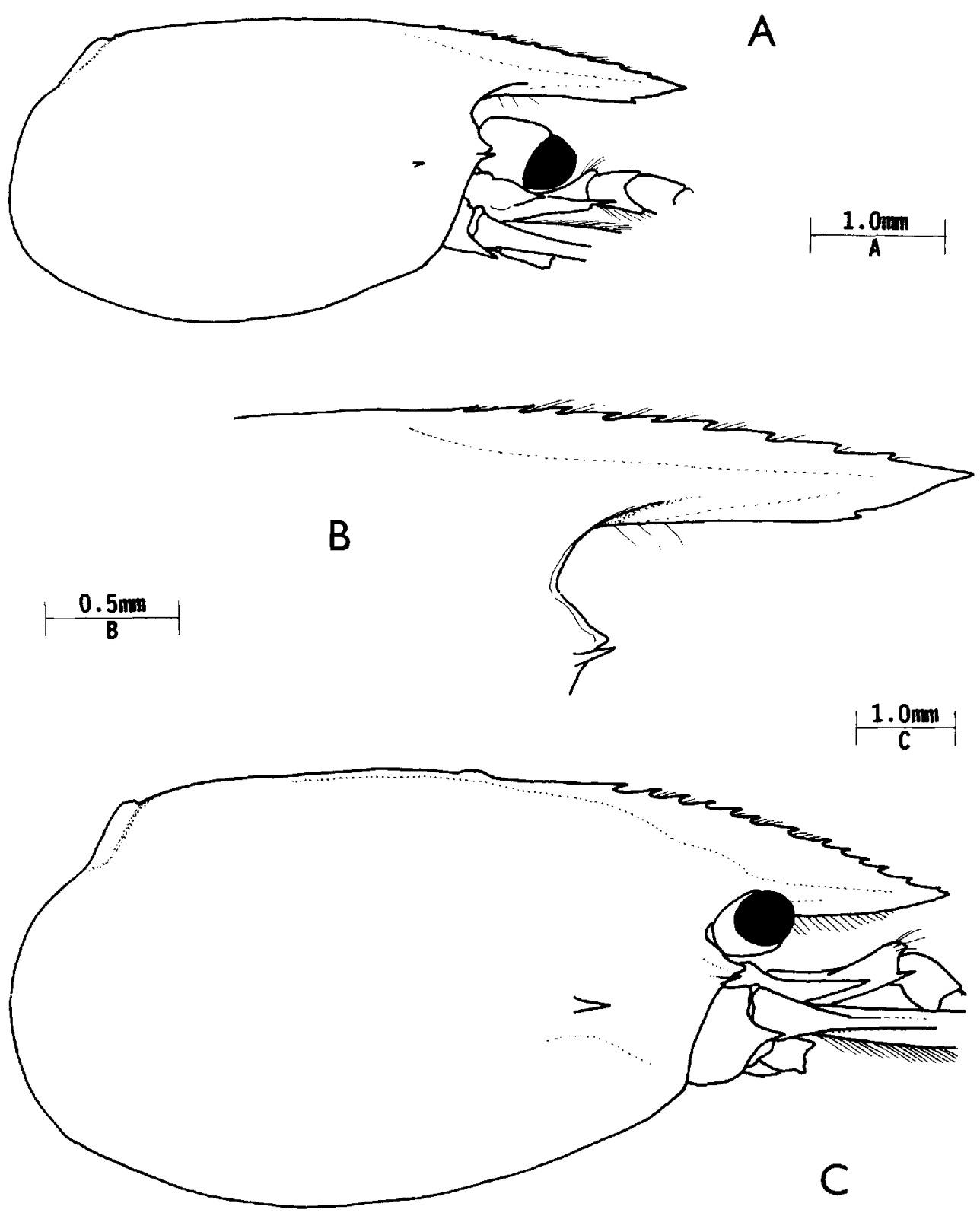

Fig.23. Periclimenes pholeter Holthuis, Red Sea, juvenile, CL $2.7 \mathrm{~mm}$. A, carapace and antennular peduncles, lateral; B, rostrum. Fiji, ovigerous female, $\mathrm{CL} 7.8 \mathrm{~mm}$; carapace and antennal peduncles. 
in a commensal association in the Palaemonidae. All the other species from traps and most of the deep-sea pontoniine shrimps also have biunguiculate dactyls. Periclimenes poupini is known to be an associate of an anemone found on gastropod shells occupied by pagurids of the genus Trizopagurus. Even if the deepsea specimens of $P$. pholeter have retained a commensal association with some host, it would appear that this habit has been lost or rendered unnecessary in the largely predator-free shallow water anchialine habitat, where there would be few suitable candidates for such an association. The marked preponderance of females in these deep-water specimens suggests that some form of hermaphroditism may occur in this habitat.

Several small juveniles are present in the collection. In the smallest specimens the rostrum is rather shallower than in the adults, about 0.58 of the carapace length, and not exceeding the antennular peduncle. The epigastric spine is lacking and the dorsal rostral carina bears about 9 low teeth, the proximal teeth particularly slender, with a single tooth ventrally. The cornea is about 0.15 of the carapace length, compared with about 0.08 in the adult.

Through the kindness of Dr C.H.J.M. Fransen, it has also been possible to examine three further specimens of $P$. pholeter from Fiji, (CLs 6.2, 6.6, $7.8 \mathrm{~mm}$ ), collected by Dr S. Choy in an anchialine pool near mangrove habitats. These closely resemble the Red Sea - western Indian Ocean specimens, except that the rostrum is distinctly shorter, appearing deeper, and not exceeding the intermediate segment of the antennular peduncle. The rostral dentition is $12-13 / 10$ and the smaller male and female specimens lack epigastric tooth. The rostral differences do not appear sufficient to suggest that these specimens should require separate specific status, although a subspecific designation might be appropriate. Until further material from the same region is available to indicate the full range of rostral variations, these specimens are considered to be conspecific with the previously known material. No other morphological differences could be detected between the two lots of specimens.

The ova of the single ovigerous female, CL $13.0 \mathrm{~mm}$, are numerous and small, length about $0.5 \mathrm{~mm}$.

Distribution. Type locality - Ras Muhammed Crack, Sinai Peninsula. Otherwise previously reported only from Aldabra, Seychelle Islands.

\section{Periclimenes lanipes Kemp, 1922}

Fig. 24

\section{Restricted synonymy}

Periclimenes lanipes Kemp, 1922: 156-158, pl. fig.4.-Bruce, 1971a: 11-15, figs $3,4,5 \mathrm{c}, \mathrm{d}$.

Periclimenes (Harpilius) brooki.-Johnson, 1961: 59 (non Anchistia Brockii De Man, 1888).

Periclimenes brockii.-Johnson, 1979: 33 (non Anchistia Brockii
De Man, 1898).

Material examined. 1 ovig. female, Singapore Straits, Fisheries Research Collection, stn $66,50 \mathrm{~m}, 27$ Jan. 1955, det. D.S. Johnson, (J.7879), ZRC 1989.89. (ii) male, Singapore Straits, Fisheries Research Collection, stn B60, 38$40 \mathrm{~m}, 14$ Aug. 1955, det. D.S. Johnson (J.7878), ZRC 1989.2290

Remarks. Johnson $(1961,1979)$ reported the occurrence of $P$. brocki in the Singapore Straits region. The material from the Zoological Reference Collection, National University of Singapore, has recently been re-examined and found it not to correspond to the species, P. brocki, reported as Anchistia Brockii from Ambon by De Man (1888). The female specimen is largely complete, with most appendages detached, and has a carapace length of $3.9 \mathrm{~mm}$, with a rostral dentition of $11 / 1$. It agrees precisely with the description provided by Kemp (1922), particularly with reference to the dense woolly setation of the pereiopods and is also at once distinguished from $P$. brocki (De Man) by the presence of an accessory tooth on the dactyls of the ambulatory pereiopods. The ambulatory dactyls are, as previously reported, densely provided with woolly setae, which largely obscure the dactyl. On cleaning and mounting a detached pereiopod it was also revealed that these setae also obscure several large spines on the distal propod, which were not reported by Kemp. Unfortunately, one spine was accidentally detached (indicated by dashed line) and its exact position could not be discerned with complete certainty. The merus is distoventrally acute, with four small mobile spines proximally, as reported by Kemp (1922), a feature not known in any other species of Periclimenes. The male specimen (CL $3.0 \mathrm{~mm}, \mathrm{R}$. $9 / 1$ ) is similar, with all the pereiopods detached, except the minor second pereiopod, which is in an early stage of regeneration. The major chela has the palm about 1.4 times the carapace length. The first pleopod has the basipodite broad, about 1.6 times longer than wide, with the distolateral angle acutely produced, setose. The endopod is about 0.75 of the basipodite length, 3.0 times longer than wide, 0.6 of the endopod length. The medial margin bears a very small process at about 0.6 of its length, the proximal medial margin with 11 small simple spinules. The distal 0.6 of the lateral margin bears 13 short plumose setae and the distal margin is rounded, non-setose. The second pleopod has the basipodite 2.0 times longer than wide, about 1.25 times the first basipodite length, with the distolateral angle strongly produced, rounded, setose. The endopod is about 5.5 times longer than broad, subequal to the basipodite length, with the appendices at about 0.33 of the medial margin length. The appendix masculina has the corpus subcylindrical, about 0.3 of the endopod length, 7.0 times longer than wide, with three stout serrulate spines distally, the longest about 0.66 of the corpus length; the 
distoventral margin bears three shorter, feebly spinulate spines. The appendix interna is slender, slightly shorter than the appendix masculina, with a few distal cincinnuli.

Periclimenes lanipes is an associate of gorgonocephalid basket-stars, but there is no record of any host for these Singapore specimens.

Distribution. Type locality - Mergui Archipelago, $12^{\circ} 48^{\prime} \mathrm{N} 98^{\circ} 16^{\circ} 10^{\prime \prime} \mathrm{E}, 44 \mathrm{~m}$. Also known from Somalia, Zanzibar, Madagascar, northern South China Sea, Queensland and New Caledonia.
Parapontonia nudirostris Bruce, 1968

Figs $25-27$

Restricted synonymy

Parapontonia nudirostris Bruce, 1968: 1149-1156, figs 1-5.Bruce, 1971: 18-19.-Bruce, 1981: 9,26.-Bruce, 1983: 204.

Material examined. (i) 1 male, 1 ovig. female, stn 34/0/1, Davies Reef, 1850'S 147 $39^{\prime} \mathrm{E}, 10 \mathrm{~m}$, south reef front, 22 Oct. 1988, coll. K. Fabricius, NTM Cr.006837. (ii) 1 juv. male, 3 juveniles, stn 24/10/88, Davies Reef, 18 $50^{\prime}$ 'S

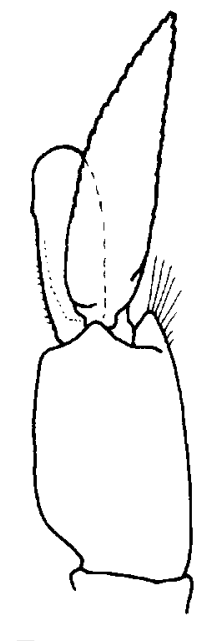

D

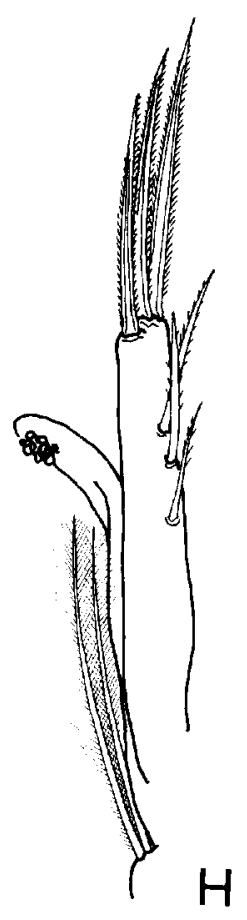

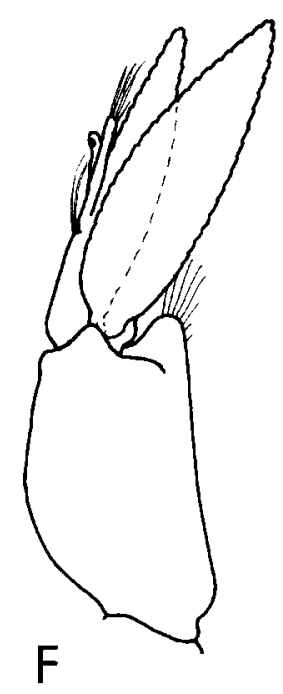

$\mathrm{F}$

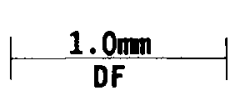

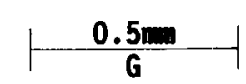
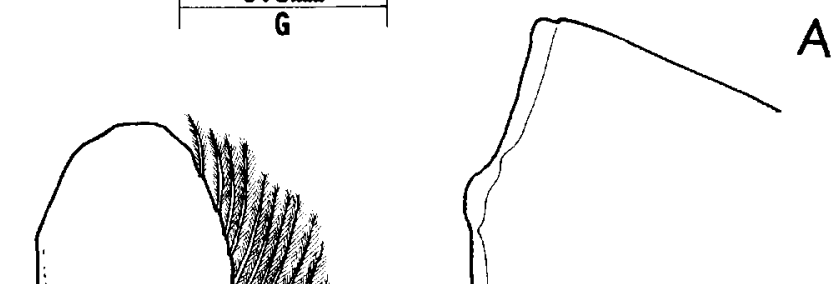

$A$ 
147³9'E, 7 m, lagoon, 24 Oct. 1988, coll. K. Fabricius, NTM Cr. 006838 .

Hosts. (i) Tropiometra afra (Hartlaub); (ii) Himerometra robustipinna (P.H. Carpenter) (Echinodermata, Crinoidea).

Remarks. The adult pair of specimens conform closely to the original description but some additional details can now be provided.

The cornea is conoidally produced but the process is not as conspicuously developed as in the type specimens. The second pereiopods of the male are more robust than in the holotype, with the major chela about 1.85 of the carapace length, about 2.8 times longer than the proximal depth, subcylindrical, slightly compressed and feebly swollen proximally. The fingers are robust, the dactylus about 0.5 of the palm length, instead of 0.9 , with the dactyl 0.33 times longer than proximal depth, curved, with a stout curved tip, the cutting edge with four low blunt similar teeth over the central half of the cutting edge. The fixed finger is similar, with four similar low blunt teeth on the proximal half of the cutting edge length, with a further low tooth distally, separated from the fourth tooth by a deeper notch, with a deep notch adjacent to the stout tip into which the tip of the dactyl fits. The minor second pereiopod is similar, about 0.9 of the major pereiopod length. The dactyls of the ambulatory pereiopods are all distinctly biunguiculate, the propod robust, without distoventral or ventral spines. The endopod of the male first pleopod is about 0.45 of the exopod length, 4.0 times longer than central width, slightly curved medially, unexpanded, distally rounded and without a medial accessory lobule, the proximal half of the medial border with four very slender simple spiniform setae proximally and three shorter, stouter simple spinules distally, the distolateral margin bearing six stout feebly plumose setae. The endopod of the second pleopod bears the appendix masculina at about 0.5 of the length, the corpus is subcylindrical, feebly tapered distally with three ventromedial spines, densely serrulate, of increasing length distally, the longest spine terminal, about 1.25 times the corpus length, reaching to about 0.9 of the endopod length: the appendix interna is slender, distinctly exceeding the appendix masculina, with few distal cincinnuli only. The dorsal telson spines are very small, as in the type specimens, in the female at 0.54 and 0.77 of the telson length, the lateral posterior spines are distinctly larger than the dorsal spines, the intermediate spines are about 0.13 of the dorsal telson length, 6.5 times longer than the proximal width, robust and distally blunt, the submedian spines are about 0.5 of the intermediate spine length, very acute distally and setulose medially and laterally.

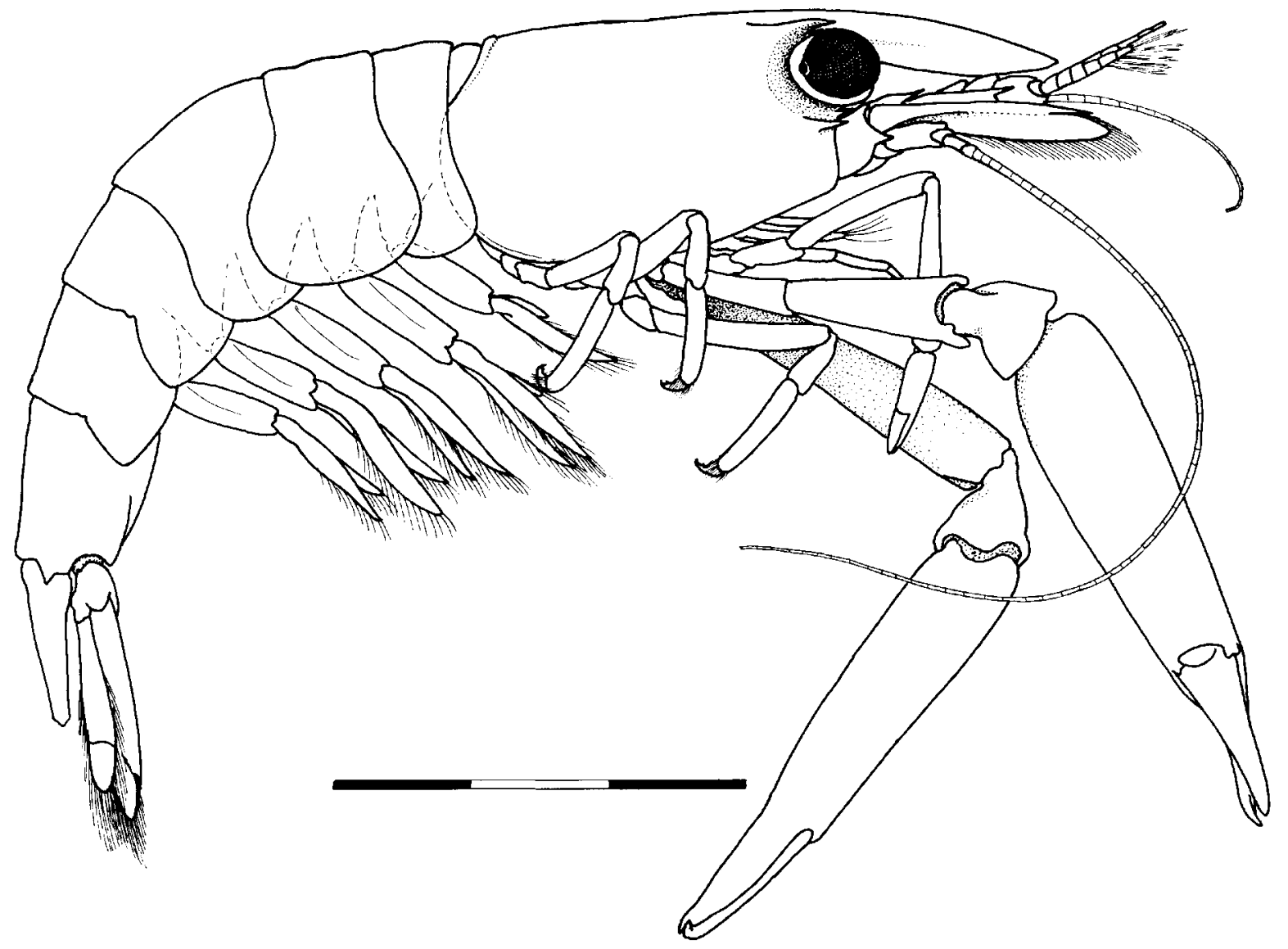

Fig.25. Parapontonia nudirostris Bruce, Davies Reef, male, scale bar in millimetres. 
The juvenile specimens, particularly the smallest specimen, show a number of interesting features, which emphasise the close relationship of Parapontonia to the genus Periclimenes, and illustrate their disappearance with growth. In the smallest specimen, CL. $1.1 \mathrm{~mm}$, the orbit is already of the adult form, deep, with a well-

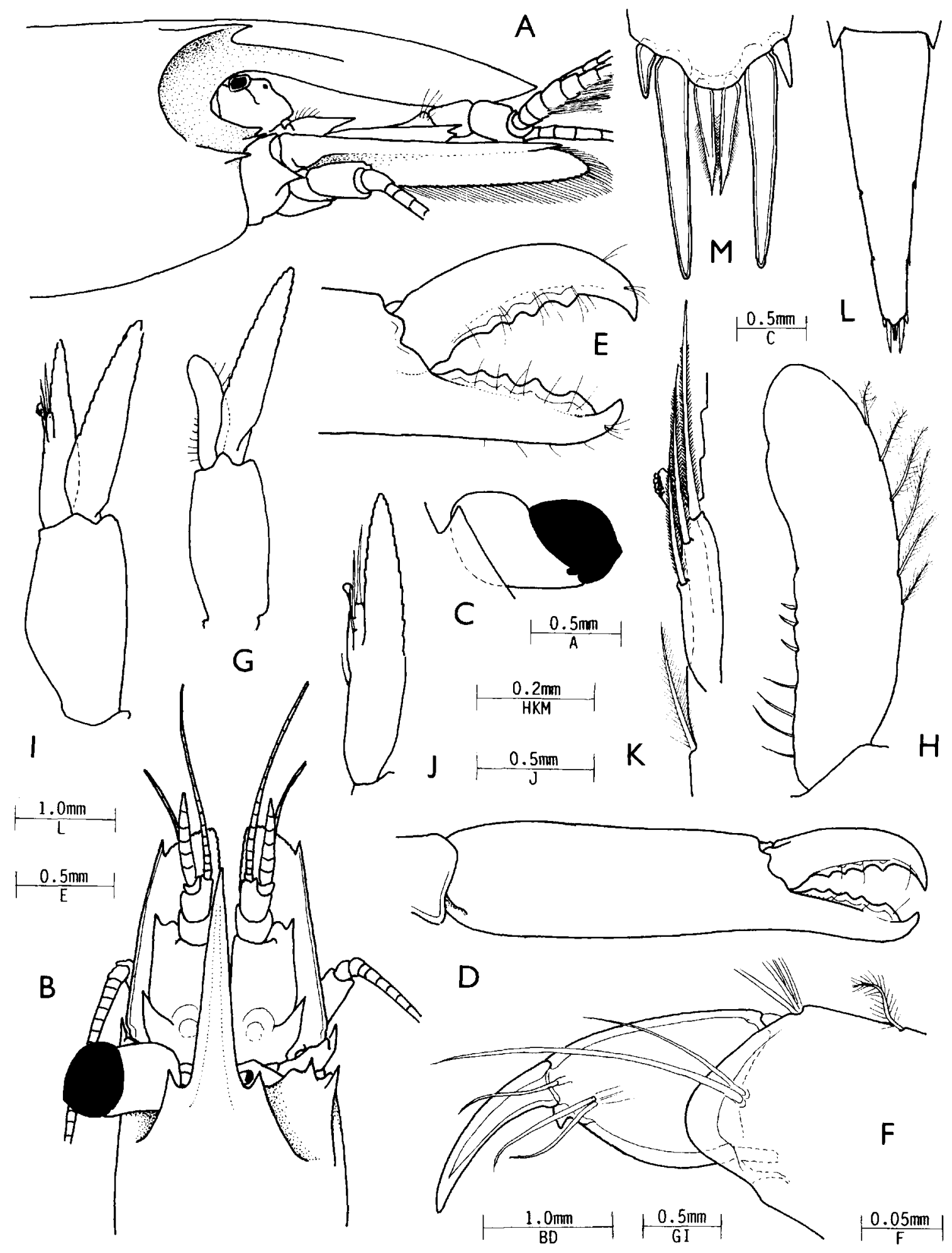

Fig.26. Parapontonia nudirostris Bruce, Davies Reef, male. A, anterior carapace, rostrum and antennal peduncles, lateral; B, same, dorsal; C, eye; D, major second pereiopod, chela; E, same, fingers; F, third pereiopod, distal propod and dactyl; G, first pleopod; H, same, endopod; I, second pleopod; J, same endopod; $\mathrm{K}$, same, appendix masculina and appendix interna; $\mathrm{L}$, telson; $\mathrm{M}$, same, posterior spines. 


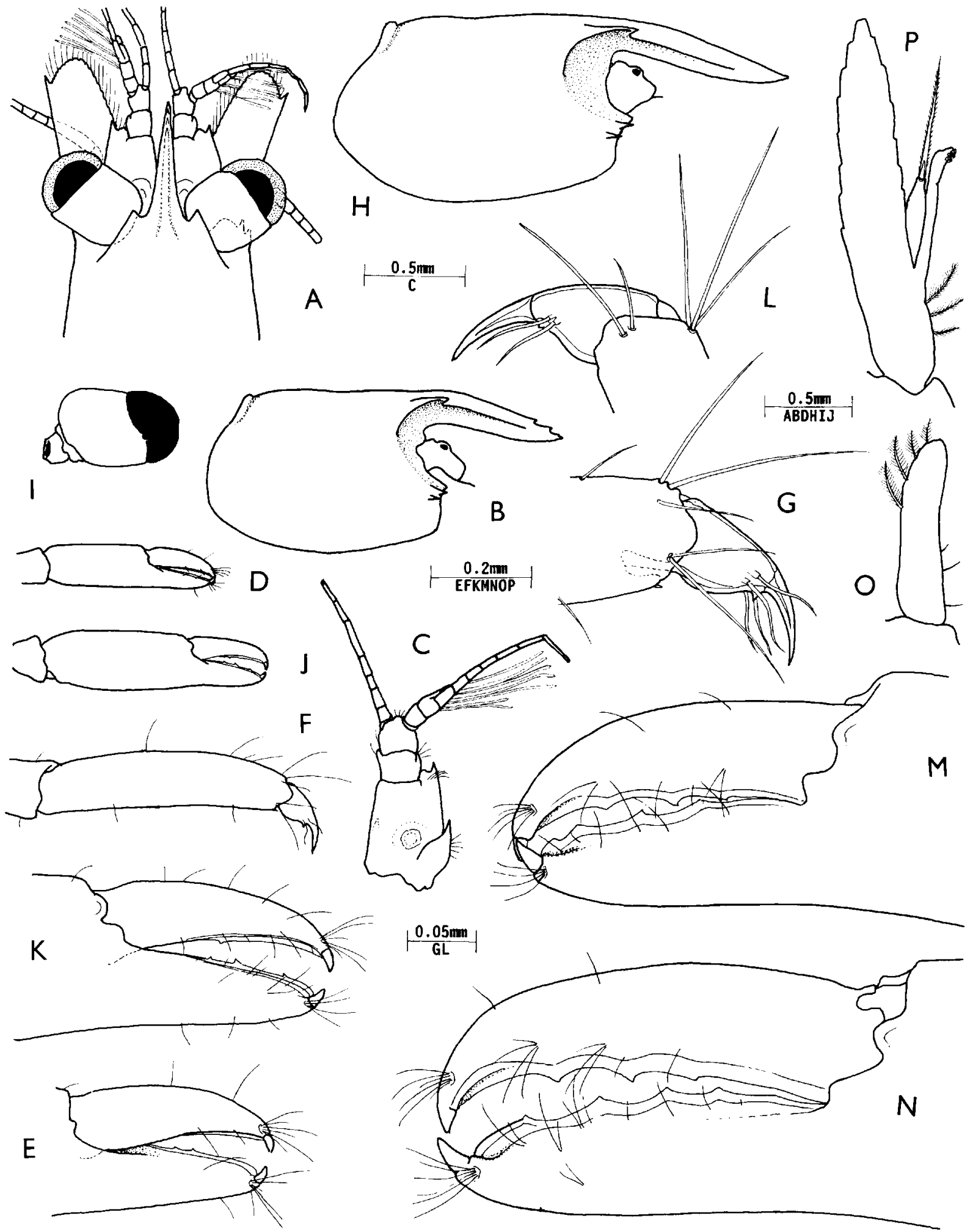

Fig.27. Parapontonia nudirostris Bruce, Davies Reef, juveniles. A, anterior carapace and appendages, dorsal; B, carapace and rostrum, lateral; C, antennule; D, second pereiopod, chela; E, same, fingers; F, third pereiopod, propod and dactyl; G, same, distal propod and dactyl; H, carapace and rostrum, lateral; I, eye; J, second pereiopod, chela; K, same fingers; L, third pereiopod, distal propod and dactyl; $M, N$, second pereiopod chela, fingers; $O$, first pleopod, endopod; $P$, second pleopod, endopod. A-G, CL $1.1 \mathrm{~mm}$; H-L, CL 1.6 $\mathrm{mm} ; \mathrm{M}, \mathrm{CL} 1.7 \mathrm{~mm}$; N-P, CL $1.8 \mathrm{~mm}$. 
developed supraorbital tooth and the antennal and hepatic spines in their adult positions. The rostrum is about 0.75 of the carapace length, but with three small acute distal teeth. The cornea is globular, withoul any trace of a distal conoidal process. It seems most likely that the juveniles of those species of Periclimenes in which the cornea is conoidally produced, once placed in a separate subgenus Corniger Borradaile, 1915, will also have globular or hemispherical corneae in their juvenile stages and subsequently be liable to misidentification. The second pereiopods are about 0.95 of the carapace length, the fingers 0.68 of the palm length, with a single small acute tooth on the cutting edge of the fixed finger, the cutting edge of the dactyl entire. The ambulatory propods are robust, about 4.4 times longer than the central width, and with a single minute distoventral spine. The dactyl is very similar to that of the adult, with a distinct acute ventral accessory tooth. The antennule has the rami of the upper flagellum fused for the two proximal segments, with shorter free ramus of one segment, with four groups of aesthetascs, and the longer free ramus of 7 segments. The lower flagellum has 7 slender segments. The stylocerite is well developed and the statocyst contains a small ovoid statolith. The next largest specimen, with a carapace length of $1.6 \mathrm{~mm}$, has lost the rostral teeth and also the spinule on the distoventral angle of the ambulatory propod. The accessory tooth on the ambulatory dactylus is rather poorly developed. The cornea remains globular and the fixed finger of the second pereiopod chela has three small acute teeth, with a single similar tooth on the dactylus. The next larger specimen, carapace length $1.7 \mathrm{~mm}$, shows further development of the second pereiopod chela, with three small acute teeth on the dactylar cutting edge and the further incipient development of a fourth distal tooth on the fixed finger. The largest specimen, CL. $1.8 \mathrm{~mm}$, still with a globular cornea, is a juvenile male with the second pereiopod bearing a fusiform appendix masculina with a single finely serrulate distal spine, about 1.4 times the length of the corpus; the appendix interna far exceeds the corpus of the appendix masculina. The endopod of the first pleopod is about 4.0 times longer than wide, with four feeble simple spinules proximomedially and four short plumose setae distolaterally. The chela of the second pereiopod is more robust, with three dactylar teeth and four on the fixed finger.

The adults of the genus Parapontonia are distinguished from those of Periclimenes by the lack of rostral teeth, presence of well-developed epistomal horns and conoidal corneal processes, all features that may be present in some Periclimenes species (see $P$. amboinensis above). These characters are not present in the early juvenile stages, which appear to be indistinguishable from Periclimenes. The only species of Periclimenes so far described that lacks rostral teeth is $P$. insolitus Bruce, an echinoid associate known only from Hawaii, which has hemispherical corneae and lacks epistomal horns.

Parapontonia nudirostris has been previously reported in association with both the present hosts.
Distribution. Type locality - Tiaré Bay, Nouméa, New Caledonia. Also previously reported from several Queensland localities, North Stradbroke Island, Heron Island, One Tree Island, Lizard Island and Sudbury Reef.

ACKNOWLEDGMENTS. I am most grateful to Mr S.J. Keable for the opportunity to examine the trap-caught shrimps from Lizard Island, and Ms K. Fabricius for the Great Barrier Reef crinoid associates. The loan of specimens by Dr C.H.J.M. Fransen, Dr G.C.B. Poore, Dr Verena Stagl, Dr M. Türkay, and Mrs Yang Chan Man, from material in their reference collections, is also much appreciated. Dr J.C. Markam kindly identified the isopod parasite. The most helpful comments of Dr Fenner A. Chace, who reviewed this communication, are also much appreciated.

\section{References}

Alcock, A., 1901. A Descriptive Catalogue of the Indian DeepSea Crustacea Decapoda Macrura and Anomala in the Indian Museum. Being a revised Account of the Deep-Sea Species collected by the Royal Indian Marine Survey Ship Investigator, iv $+286 \mathrm{pp}, 3$ pls.

Alcock, A. \& A.R. Anderson, 1894. An account of a recent collection of Deep-Sea Crustacea from the Bay of Bengal and the Laccadive Sea. Natural History Notes from H.M. Indian Marine Survey Steamer "Investigator", Commander C.E. Oldham R.N., commanding. Series no. 14. Journal of the Asiatic Society of Bengal 63(2): 141-185, pl.9.

Balss, H., 1915. Die Decapoden des Roten Meeres. 1. Die Macruren. Expedition S.M. Schiff "Pola" in das Rote Meer. Nördliche und südliche Hälfte, 1895/96 - 1897/98. Zoologische Ergebnisse XXX. Berichte der Kommission für ozeanographische Forschungen. Denkschriften der Mathematisch - Naturwissenschaftlichen Klasse der Kaiserlichen Akademie der Wissenschaften 91 (suppl.): 1-28, figs 1-30.

Berggren, M. \& I. Svane, 1989. Periclimenes ingressicolumbi, new species, a pontoniine shrimp associated with deepwater echinoids off San Salvador Island in the Bahamas, and a comparison with Periclimenes milleri. Journal of Crustacean Biology 39(3): 432-444, figs 1-6.

Borradaile, L.A., 1898. A revision of the Pontoniidae. Annals and Magazine of Natural History (7)2: 376-391.

Borradaile, L.A., 1915. Notes on Carides. Annals and Magazine of Natural History (8)15: 205-215.

Borradaile, L.A., 1917. On the Pontoniinae. The Percy Sladen Trust Expedition to the Indian Ocean in 1905, under the leadership of $\mathrm{Mr}$ J. Stanley Gardiner. The Transactions of the Linnean Society of London, Zoology (2) 17: 323-396, pls 52-57.

Bruce, A.J., 1968. A report on some pontoniid shrimps from New Caledonia (Crustacea Decapoda Natantia). Bulletin du Muséum National d'Histoire Naturelle, Paris (2)39(6): 1148-1171, figs 1-10.

Bruce, A.J., 1971. Periclimenes attenuatus sp. nov. (Crustacea, Decapoda, Natantia, Pontoninae), a new commensal shrimp from the Duke of York Islands. Pacific Science 25(4): 533-544, figs 1-5. 
Bruce, A.J., 1971a. Records of some rare pontoniinid shrimps from Australian waters, with remarks upon the mouthparts of some species of the genus Periclimenes Costa, 1844. Zoologische Verhandelingen, Leiden 114: 1-32, figs 1-9.

Bruce, A.J., 1972. A review of information upon the coral hosts of commensal shrimps of the sub family Pontoniinae, Kingsley, 1879 (Crustacea, Decapoda, Palaemonidae). Proceeding of the Symposium on Corals and Coral Reefs, 1969. Marine Biological Association of India: 399-418, figs 1-2.

Bruce, A.J., 1973. Notes on some Indo-Pacific Pontoniinae, XXIII. Tectopontonia maziwiae gen. nov., sp. nov., a new coral associate from Tanganyika (Decapoda, Palaemonidae). Crustaceana 24(2): 169-190, figs $1-4$.

Bruce, A.J., 1979. Records of some pontoniinid shrimps from the South China Sea. Cahiers de L'Indo-pacifique 1(2): 215-248.

Bruce, A.J., 1981. Pontoniine shrimps of Heron Island. Atoll Research Bulletin 245: 1-33.

Bruce, A.J., 1983. The pontoniine shrimp fauna of Australia. Memoirs of the Australian Museum 8: 195-218.

Bruce, A.J., 1983a. Expédition Rumphius II (1975). Crustacés parasites, commensaux, etc. (Th. Monod éd). IX. Crustacés Décapodes (I: Natantia Pontoniinae). Bulletin du Muséum National d'Histoire Naturelle, Paris 4(a)(A3): 871-902, figs $1-10$.

Bruce, A.J., 1987. Re-descriptions of two little-known IndoWest Pacific palaemonid shrimps, Periclimenes calmani Tattersall and $P$. delagoae Barnard. Journal of Natural History 21(6): 1415-1432, figs 1-9.

Bruce, A.J., 1987a. Periclimenes milleri sp. nov., a new echinoid associated pontoniine shrimp form the Bahamas. Bulletin of Marine Science 39(3): 637-645, figs 1-5.

Bruce, A.J., 1988. Typton nanus sp. nov., a new commensal shrimp (Crustacea : Decapoda : Palaemonidae) from the Australian North West Shelf. The Beagle, Records of the Northern Territory Museum of Arts and Sciences 4 (1987): 49-56, figs $1-5$.

Bruce, A.J., 1990a. Periclimenes poupini sp. nov., a new anemone-associated shrimp from deepwater traps (Crustacea: Decapoda: Palaemonidae). Bulletin du Muséum National d'Histoire Naturelle, Paris, $4^{\mathrm{e}}$ Ser., 11 (1989) A4: 851-863, figs 1-7.

Bruce, A.J., 1990h. Crustacea: Decapoda: 5. Deep-sea Palaemonoid shrimps from New Caledonian waters. Pp. 149-215, figs 1-39. In A. Crosnier (ed.). Résultats des Campagnes MUSORSTOM, 6. Mémoires du Muséum National d'Histoire Naturelle, 145.

Bruce, A.J., 1991. Shallow-water palaemonoid shrimps from New Caledonia (Crustacea : Decapoda). Pp. 221-279, figs 1-31. In B. Richer de Forges (ed.). Le Benthos des Fonds Meubles dans les Lagons de Nouvelle Caledonie, 1: Études et Théses; Paris, ORSTOM.

Devaney, D.M. \& A.J. Bruce, 1987. Crustacea Decapoda (Penaeidea, Stenopodidea, Caridea and Palinura) of Eniwetak Atoll. 17. Pp. 221-233. In D.M. Devany et al. (eds). The Natural History of Eniwetak Atoll 2. Biogeography and Systematics. United States Department of Energy.

Gurney, R., 1938 The larvae of the Decapod Crustacea. Palaemonidae and Alpheidae. Scientific Reports of the Great Barrier Reef Expedition 6: 1-60, figs 1-265.

Hart, C.W., jr., R.B. Manning \& T.M. Iliffe, 1986. The fauna of Atlantic marine caves: evidence of dispersal by sea floor spreading while maintaining ties to deep waters. Proceedings of the Biological Society of Washington 98(1): 288-292, fig.l.

Holthuis, L.B., 1952. The Decapoda of the Siboga Exhibition.
Part XI. The Palaemonidae collected by Siboga and Snellius Expeditions with remarks on other species. II. Subfamily Pontoniinae. Siboga Expedition Monograph 39a10: 1-252, 1-110, table 1.

Holthuis, L.B., 1953. Enumeration of the Decapod and Stomatopod Crustacea from Pacific Coral Islands. Atoll Research Bulletin 24: 1-66.

Holthuis, L.B., 1958. Contributions to knowledge of the Red Sea, 8. Crustacea Decapoda from the northern Red Sea (Gulf of Aqaba and Sinai Peninsula). 1. Macrura. Bulletin of the Sea Fisheries Research Station, Israel 17(8-9): $1-40$, figs $1-15$.

Holthuis, L.B., 1973. Caridean shrimps found in land-locked saltwater pools at four Indo-West Pacific localities (Sinai Peninsular, Funafuti Atoll, Maui and Hawaii Islands), with the description of one new genus and four new species. Zoologische Verhandelingen, Leiden 128: 1-48, figs 1-13, pls 1-7.

Holthuis, L.B., 1981. Description of three new species of shrimps (Crustacea: Decapoda: Caridea) from Pacific Islands. Proceedings of the Biological Society of Washington 94(3): 787-800, figs 1-4.

Johnson, D.S., 1961. A synopsis of the Decapod Caridea and Stenopodidea of Singapore with notes on their distribution and a key to the genera of Caridea occurring in Malayan Waters. Bulletin of the National Museum, Singapore 30: 44-79, 1 pl.

Johnson, D.S., 1979. Prawns of the Malacca Straits and Singapore Waters. Journal of The Marine Biological Association of India 18(1) (1976): 1-54

Kemp, S., 1922. Notes on the Crustacea Decapoda in the Indian Museum. XV. Pontoniinae. Records of the Indian Museum, Calcutta 24: 113-288, figs 1-105, pls 3-9.

Kemp, S., 1925. Notes on the Crustacea Decapoda in the Indian Museum. XVII. On various Caridea. Records of the Indian Museum, Calcutta 27: 249-343, figs 1-24.

King, M.G., 1984. The species and depth distribution of deep water caridean shrimps (Decapoda, Caridea) near some southwest Pacific Islands. Crustaceana 47(2): 174-191, figs 1-7.

Ledoyer, M., 1984. Les Caridea (Crustacea: Decapoda) des herbiers de phanerogames marines de Nouvelle Calédonie (Région de Nouméa) (Systematique, ecologie, variations nycthemerales et vicariance). Zoologische Verhandelingen, Leiden 211: 1-58, figs 1-21.

Man, J.G. de, 1888. Bericht über die von Herm Dr. J. Brock im indischen Archipel gesammelten Decapoden und Stomatopoden. Archiv für Naturgeschichte 53(1): 215-600, pls 7-229.

Man, J.G. de, 1902. Die von Herr Professor Kükenthal in Indischen Archipel gesammelten Dekapoden and Stomatopoden. Pp. 467-929, pls 19-27. In Kükenthal, W., Ergebnisse einer zoologischen Forschungsreise in den Molukken und Borneo. Abhandlunghen hrsg. von der Senckenbergishen naturforschenden Gesellschaft 25.

Miyake, S. \& T. Fujino, 1968. Pontoniinid shrimps from the Palau Islands (Crustacea, Decapoda, Palaemonidae). Journal of the Faculty of Agriculture, Kyushu University 10(3): 339-431, figs $1-8$.

Nobili, G., 1901. Decapodi and Stomatopodi Eritrei del Museo Zoologico dell' Università di Napoli. Annuario del Museo Zoologico della R. Università di Napoli (N.S.) (3): 1-20.

Nobili, G., 1906. Diagnoses préliminaires des Crustacés, Décapodes et Isopodes nouveaux receuillis par M. Dr. G. Seurat aux iles Touamotou. Bulletin du Muséum d'Histoire Naturelle, Paris 12: 256-270.

Nobili, G., 1907. Ricerche sur Crostacei della Polinesia. 
Decapodi, Stomatopodi, Anisopodi \& Isopodi. Memoire dell' Accademia della Scienza di Torino 57(2): 351-430, pls 1-3.

Rathbun, M.J., 1906. The Brachyura and Macrura of the Hawaiian Islands. The Bulletin of the United States Fisheries Commission 23(3): 827-930, figs 1-79, pls 3-24.

Tattersall, W.M., 1921. Report on the Stomatopoda and Macrurous Decapoda collected by $\mathrm{Mr}$ Cyril Crossland in the Sudanese Red Sea. Proceedings of the Linnean Society of London, Zoology 34: 345-398, pls 27-28.

Turkäy, M., 1986. On the composition of the deep Red Sea invertebrate fauna in comparison to that of Mediterranean. Pp. 233-242. In Z. Dubinsky \& Y. Steinberger (eds). Environment Quality and Ecosystem Stability. III A/B, Bar Ilan University Press.

Wear, R.G. \& L.B. Holthuis., 1977. A new record of the anchialine shrimp Ligur uveae (Borradaile, 1899). (Decapoda, Hippolytidae). Zoologische Mededelingen, Leiden 51(8): 125-140, fig. 1 , pls $1-2$.

Accepted October 2, 1990 